OPEN ACCESS

Edited by:

Fang Liu,

Guangzhou University of Chinese

Medicine, China

Reviewed by:

Zhiqiang Pei,

Northwestern University, United States

Wang Shuang,

Chinese Academy of Sciences, China

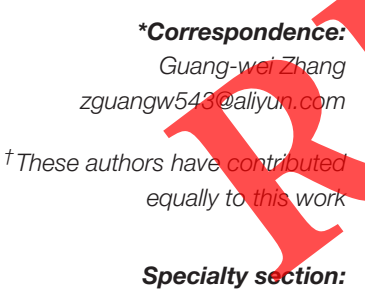

This article was submitted to

Nanoscience,

a section of the journal

Frontiers in Chemistry

Received: 20 May 2020

Accepted: 30 July 2020

Published: 29 October 2020

Citation:

Zhang D, Ma X-I, Gu Y, Huang H and Zhang G-w (2020) Green Synthesis of

Metallic Nanoparticles and Their

Potential Applications to Treat Cancer.

Front. Chem. 8:799.

doi: 10.3389/fchem.2020.00799

\section{Green Synthesis of Metallic Nanoparticles and Their Potential Applications to Treat Cancer}

\author{
Dan Zhang ${ }^{\dagger}$, Xin-lei $\mathrm{Ma}^{\dagger}$, Yan Gu, He Huang and Guang-wei Zhang * \\ Department of Cardiology, First Hospital of Jilin University, Changchun, China
}

Nanoparticle synthesis using microorganisms and plants by green synthesis technology is biologically safe, cost-effective, and environment-friendly. Plants and microorganisms have established the power to devour and accumulate inorganic metal jons from their neighboring niche. The biological entities are known to synthesize nanoparticles both extra and intracellularly. The capability of a diving system to utilize its intrinsic organic chemistry processes in remodeling inorganic metal ions into nanoparticles has opened up an undiscovered area of biochemical analysis. Nanotechnology in conjunction with biology gives rise to an advanced area of nanobiotechnology that involves living entities of both prokaryotic and eukaryotic origin, such as algae, cyanobacteria, actinomycetes, bacteria, viruses, yeasts, fungi, and plants. Every biological system varies in its capabilities to supply metallic nanoparticles. However, not all biological organisms can produce nanoparticles due to their enzymatic activities and intrinsic metabolic processes. Therefore, biological entities or their extracts are used for the green synthesis of metallic nanoparticles through bio-reduction of metallic particles leading to the synthesis of nanoparticles. These biosynthesized metallic nanoparticles have a range of unlimited pharmaceutical applications including delivery of drugs or genes, detection of pathogens or proteins, and tissue engineering. The effective delivery of drugs and tissue engineering through the use of nanotechnology exhibited vital contributions in translational research related to the pharmaceutical products and their applications. Collectively, this review covers the green synthesis of nanoparticles by using various biological systems as well as their applications.

Keywords: metallic nanoparticles, green synthesis, extracellular, intracellular, tissue engineering, bio-detection

\section{INTRODUCTION}

Nanotechnology is amongst the most widely used technologies in translational research. The development of metallic nanoparticles employing biological materials by an eco-friendly approach has attracted significant attention. Nanotechnology deals with particles of a size ranging from 1 to $100 \mathrm{~nm}$, their synthesis strategy, and manipulation. This knowledge domain naturally commingles all the fields of natural sciences together with chemistry, physics, biological sciences, engineering, materials science, and computational sciences for the formulation of nanostructures (Shenton et al., 1999; Medvedeva et al., 2007). The nanostructures have different applications attributable to their new or increased properties (Tang et al., 2007; Thakkar et al., 2009) depending upon their size, distribution, and morphology. It has applications in various fields including biomedical, catalysis, 
chemical industries, cosmetics, drug delivery, electronics, environment, energy science, food and feed, health care, mechanics, optics, space industries, non-linear optical devices, single-electron transistors, and photo-electrochemical applications. The metallic nanoparticles are considered one of the most promising systems for all the aforementioned functions (Wang et al., 2005; You et al., 2013; Singh et al., 2016).

A nanoscale drug carrier acts as a single unit with respect to its properties and transport. These nanoclusters have narrow size distribution and a minimum of one dimension between 1 and 10 nanometers. The agglomerates of ultrafine particles, nanoclusters or nanoparticles, are nanopowders whereas nanocrystals are the crystals of nanoparticle size

There are two general strategies for the synthesis of nanomaterials: the top-down approach, wherein a larger structure is broken down into smaller pieces using chemical, physical, and biological energy; and the bottom-up approach, in which material is synthesized from the atomic level using various chemical, physical, or biological reactions to make a large nanostructure (Das et al., 2017). The chemical and biological methods are primarily accustomed to build nanostructured carriers (NC) employing this approach (Figure 1).

The physical and chemical strategies are in-use for the synthesis of nanoparticles. The utilization of toxic chemicals could exert potential hazards like carcinogenicity, toxicity, and environmental toxicity (Gupta and Xie, 2018). The toxicity problems are quite prominent due to the use of hazardous substances such as reducing agents, organic solvents, and stabilizers. These chemicals prevent the agglomeration of colloids. The use of toxic solvents and chemical contaminations limits the use of nanoparticles in various clinical and biomedical applications (Hua et al., 2018). Therefore, a reliable, clean, biologically appropriate, and environmental-friendly techniques is indeed required to synthesize nanoparticles (Jain et al., 2010; Thakkar et al., 2010; Kulkarni and Muddapur, 2014). The biological synthesis of nanoparticles may prove to be an attractive alternative. It includes adoption of multicellular and unicellular biological entities- bacteria (Roh et al., 2001; Nair and Thalappil, 2002; Lengke et al., 2006; Husseiny et al., 2007; Joglekar et al., 2011), actinomycetes (Ahmad et al., 2003a,b; Sastry et al., 2005), fungi Mukherjee et al., 2001, 2002; Ahmad et al., 2002, 2005; Bhainsa and D'Souza, 2006, plants Philip, 2010; Kumar et al., 2011, viruses (Lee et al., 2002 Merzlyak and Lee, 2006; Khan et al., 2013), and yeasts (Dameron et al., 1989; Kowshik et al., 2003; Gericke and Pinches, 2006a,b). The biologically synthesized nanoparticles have a broad area to study with respect to their shape, size, composition, and physicochemical properties (Mohanpuria et al., 2008). Further, biological entities may operate as a pattern for the assembly, synthesis, and organization of the nanometer scale. The present review covers the use of biological routes for the synthesis of metal oxide and metal

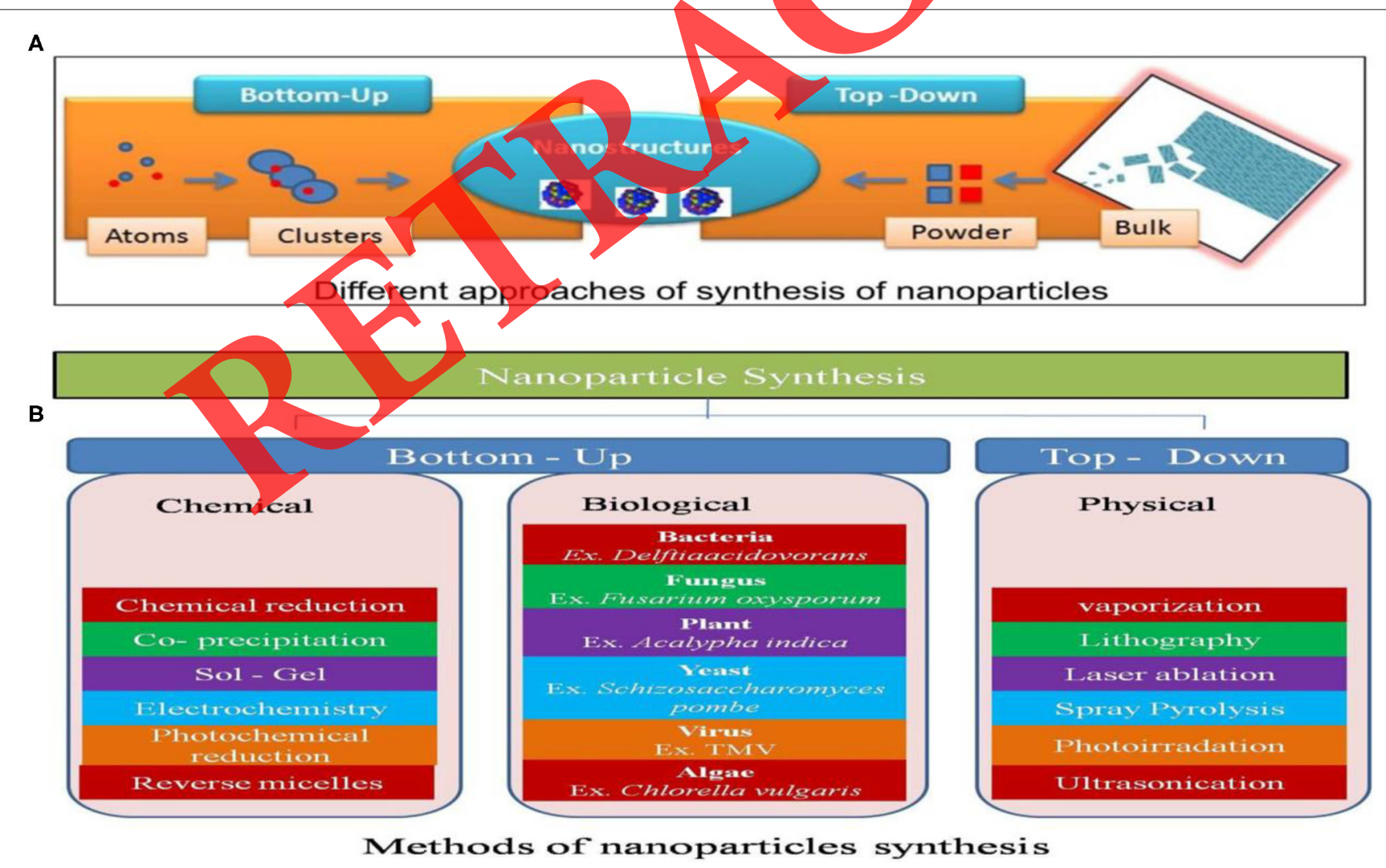

FIGURE 1 | (A,B) Approaches and method of synthesis of nanoparticles. 
nanoparticles, and various factors affecting their synthesis, and possible mechanisms employed along with likely applications of nanoparticles formed using biological factories.

\section{BIOLOGICAL SYNTHESIS OF NANOPARTICLES}

Organisms have advanced to endure in environments of high concentrations of metals (Bisen et al., 1987, 1996; Khare and Bisen, 1991). These organisms may alter the chemical nature of the toxic metals by lowering their toxicity or making them nontoxic (Singh et al., 1989, 1993; Sharma and Bisen, 1992; Sharma et al., 2001). The formation of nanoparticles is the "consequence" of the resistance mechanism of an organism in contrast to a specific metal (Figure 2). The synthesis of "Natural" biogenic metallic nanoparticle synthesis is split into two categories:

(a) Bioreduction: More stable forms of metal ions may be achieved by chemical reduction using biological means and is achieved by dissimilatory metal reduction. The metal ion is reduced and the enzyme is oxidized (Deplanche et al., 2010). This concludes in the production of impotent metallic nanoparticles which may be harmlessly recovered from a contaminated sample.

(b) Biosorption: The metal ions bind to the organism itself from an aqueous sample or soil sample. Either the metal ions are bonded to the cell wall or peptides are synthesized by some plants, bacteria, and fungi, and these synthesized peptides assembles into stable nanoparticulate structures (Yong et al., 2002).

The selection of biological methods for synthesis and engineering of nanoparticles is dependent upon several variables. The form of the metal nanoparticle to be synthesized is the most important variable. Resistance developed against a small number of metals by the organisms limit the choice of organisms. Following are a number of the microbial resources (algae, fungi, bacteria, viruses, and yeast) used for most of the frequently studied metal and metal salts nanoparticles consisting of copper, silver, gold, cadmium, platinum, palladium, cadmium sulfide, titanium dioxide, and zinc oxide (Mousavi et al., 2018; Gahlawat and Roy Choudhury, 2019).

\section{Bacteria Mediated Synthesis of Nanoparticles}

Pure gold nanoparticles were synthesized by bacterium, Delftia acidovorans (Johnston et al., 2013). Delftibactin is a small nonribosomal peptide and is considered liable for the synthesis of gold nanoparticles as it is known to induce resistance against toxic gold ions. The transition metal, gold, did not exert toxicity toward bacterium due to the formation of inert gold nanoparticles (AuNPs) bound to delftibactin (Pantidos and Horsfall, 2014). A substitutive method for gold nanoparticle synthesis by the bacterium Rhodopseudomonas capsulata was shown to produce extracellular gold napoparticles ranging in size from 10 to $20 \mathrm{~nm}$ ria NADH-Dependant Reductase (He et al., 2007). Green products may act as a stabilizing and reducing agent for AuNPs synthesis and these preparations exhibit medicinal applications (Lee et al., 2020).

Palladium (Pd), one of the members of the Platinum Group Metals (PGM) has a compilation of highly catalytically active metals, and is being employed as a catalyst for hydrogenation and dehalogenation reactions. The heavy contamination of those bacteria that had been isolated from Alpine sites with

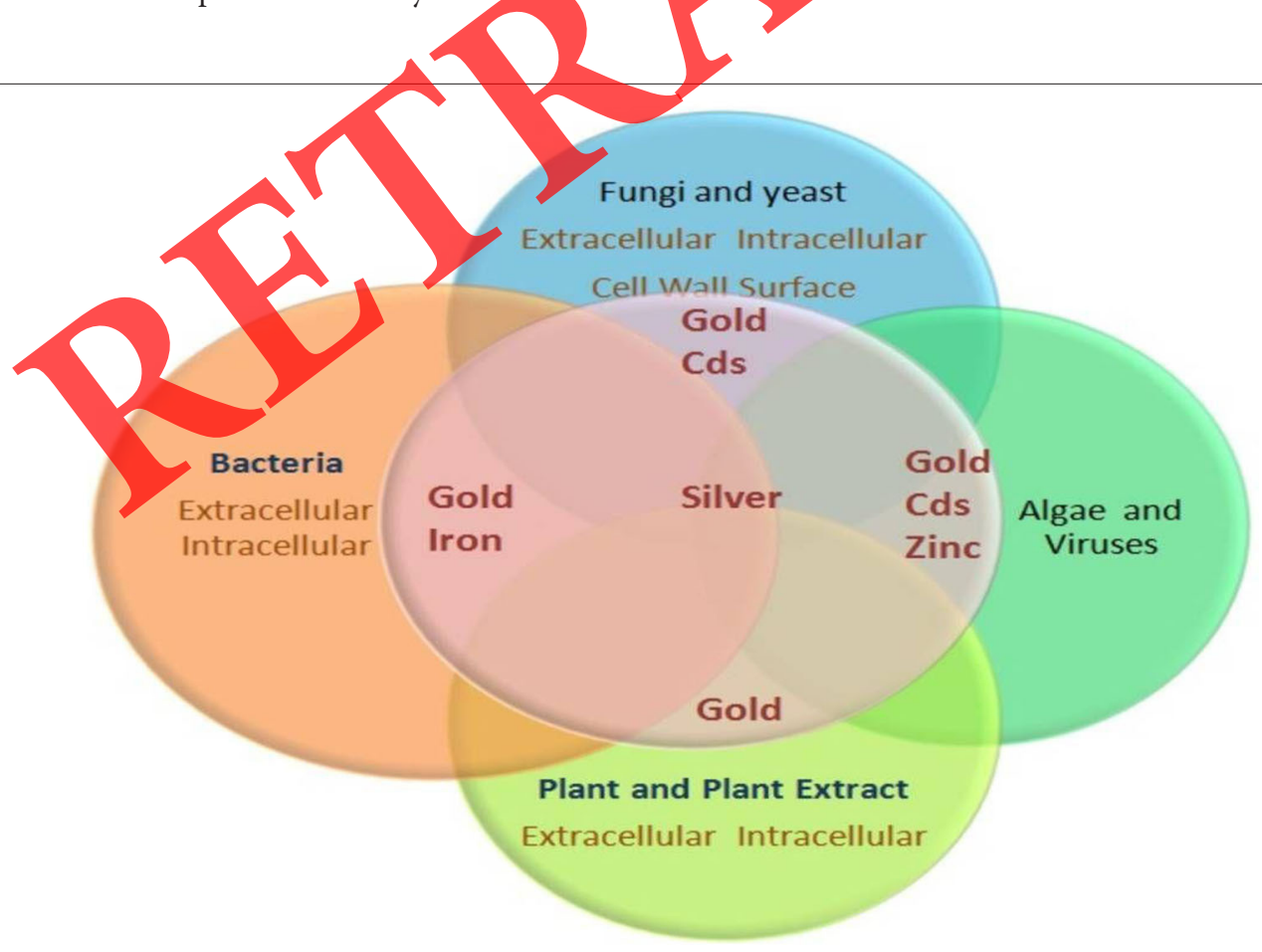

FIGURE 2 | Various biological synthesis of nanoparticles. 
that of heavy metals led to the synthesis of zero-valent Palladium $\left(\mathrm{Pd}^{0}\right)$ nanoparticles (Schlüter et al., 2014). Amongst various bacteria isolated from the site, only Pseudomonas cells exhibited the potential to produce catalytically active $\mathrm{Pd}$ nanoparticles. Furthermore, they were able to carry out the reductive dehalogenation of congeners like tri and tetrachlorinated dioxin. Escherichia coli synthesized $\mathrm{Pd}^{0}$ nanoparticles using hydrogenases present in the cells (Lloyd et al., 1998). Pd nanoparticles were synthesized on the bacterial cell envelope and may be separated easily.

The bacterium, Bacillus licheniform, reportedly produced silver nanoparticles (AgNPs) intracellularly (Kalimuthu et al., 2008). The production/synthesis of nanoparticles required $24 \mathrm{~h}$ and was demonstrated by the color modification of culture into dark brown after the augmentation of silver ions. However, as the nanoparticles were synthesized intracellularly an additional extraction step was required. Intracellular AgNPs were synthesized by the members of the Bacillus spp. subcultured in $\mathrm{AgNO}_{3}$ containing media and the reaction was completed in 7 days (Pugazhenthiran et al., 2009). The culture supernatant was tested for its capability to form metallic nanoparticles (Shahverdi et al., 2007) in $5 \mathrm{~min}$. The extracellular production of nanoparticles is recommended compared to the intracellular synthesis due to the simple purification process with the increased production rate (Das et al., 2014).

Green synthesis of AgNPs using lactic acid bacteria was demonstrated by Sintubin et al. (2009). Lactobacillus spp.,
Pediococcus pentosaceus, Enterococcus faecium, and Lactococcus garvieae was shown to synthesize the nanoparticles by many bacteria. The procedure of AgNP formation was proposed to be a two-step method. The biosorption of Ag ions on the cell wall was followed by a reduction of these ions resulting in AgNPs formation (Sintubin et al., 2009). Additionally, the cell wall could be thought to be a capping agent, maintaining their stability by stopping their aggregation.

The biosynthesis of Ag and AuNPs has been a focal point of research because of their antimicrobial attributes. The extensive studies were conducted to synthesize the metallic nanoparticles using Bacillus species due to their metal accumulating abilities (Pollmann et al., 2006; Kalimuthu et al., 2008; Pugazhenthiran et al., 2009). Bacillus sphaericus JG-A12 can collect excessive concentrations of $\mathrm{Al}, \mathrm{Cd}, \mathrm{Cu}, \mathrm{Pb}$, and $\mathrm{U}$ (Figure 3). The Uranium bioremediation from the aqueous environment was attributed to the S-layer proteins of B. sphaericus. It is a porous layer surrounding the bacterial cell and is made up of identical proteins, $\sim 5-15 \mathrm{~nm}$ thick, with the pores ranging in size from 2 to $6 \mathrm{~nm}$. The S-layer contributes up to $15 \%$ of the total proteins of the cell. The S-layer has been stated to be liable for the binding of heavy metals from the aqueous environments (Pollmann et al., 2006 ) with a capability to bind up to $20 \mathrm{mg} \mathrm{U} / \mathrm{g}$ of protein, and the $\mathrm{U}$ binds to the phosphate and carboxyl and groups of the S-layer protein (Pollmann et al., 2006).

Copper $(\mathrm{Cu})$ is not reportedly stable and is oxidized rapidly to copper oxide $(\mathrm{CuO})$ (Baco-Carles et al., 2011). Therefore,

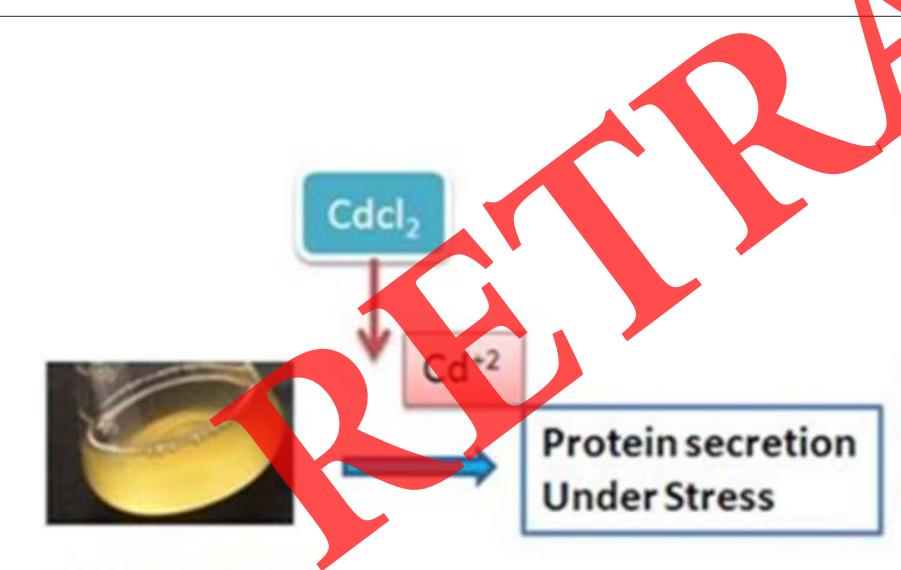

Bacterial Biomass

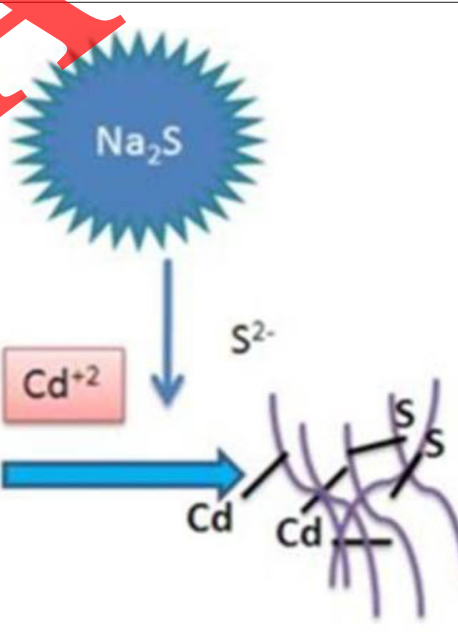

Cds nanoparticles

FIGURE 3 | Green synthesis of nanoparticles by plants. 
$\mathrm{Cu}$ nanoparticles need to be stabilized as soon as they are formulated. The synthesis of $\mathrm{Cu}$ nanoparticles using Morganella morganii is proved with the help of intracellular uptake of $\mathrm{Cu}$ ions accompanied by the means of binding of ions to a metallic ion reductase or a comparable protein ensuring in the reduction of the ion to metallic $\mathrm{Cu}^{0}$ (Baco-Carles et al., 2011). The metallic $\mathrm{Cu}$ nanoparticles then accumulate extracellularly since they are effluxed out of the cell. Morganella sp. additionally extracellularly synthesized AgNPs (Parikh et al., 2008). The $\mathrm{Cu}$ nanoparticles synthesis using $M$. morganii may be due to an Ag resistance mechanism to provide elemental $\mathrm{Cu}$ nanoparticles through silE homolog to copper-binding protein from different microorganisms (Ramanathan et al., 2013).

\section{Nanoparticle Synthesis Using Fungi}

The production of AgNPs using fungi has been the focal point of investigation because of their applications in numerous industries such as antimicrobials and electronics (Rai et al., 2008; Ummartyotin et al., 2012). The capability of the fungus Fusarium oxysporum to synthesize AgNPs has been verified with sizes ranging from 5 to $15 \mathrm{~nm}$ which had been capped through fungal proteins to lead them to becoming stable. Fusarium oxysporum could also synthesize nanoparticles extracellularly (Rai et al., 2008; Ummartyotin et al., 2012) as compared to earlier studies in which intracellular production of Ag and AuNPs, lead sulfide ( $\mathrm{PbS}$ ), cadmium sulfide (Cds), molybdenum sulfide (MoS), and zinc sulfide $(\mathrm{ZnS})$ nanoparticles intracellular production of $\mathrm{Ag}$ and AuNPs, cadmium sulfide (Cds), lead sulfide (PbS), zinc sulfide $(\mathrm{ZnS})$, and molybdenum sulfide $(\mathrm{MoS})$ had been reported (Ahmad et al., 2002, 2003a).

Aspergillus fumigatus is used to synthesize extracellular silver nanoparticles of larger sizes ranging from 5 to $25 \mathrm{~nm}$ as compared to Fusarium oxysporum, with the disadvantage of difficulty in anticipating the catalytic activity with the size difference in every batch (Bhainsa and D'Souza, 2006). However, the bioproduction of AgNPs using A. fumigatus is an attractive prospect as organism reduces $\mathrm{Ag}$ ions into nanoparticles within $10 \mathrm{~min}$ of contact (Bhainsa and D'Souza, 2006). Fungus Trichoderma reesei could also be used for extracellular production of AgNPs with a size range of $5-50 \mathrm{~nm}$ nanoparticles. It took $72 \mathrm{~h}$ to synthesize AgNPs which was appreciably slower than $A$. fumigatus and Fusarium oxysporum (Ahmad et al., 2002, 2005; Bhainsa and D'Souza, 2006). Furthermore, the use of T. reesei has an advantage over the use of other fungi since it has been an extensively-studied organism which may be manipulated for the production of an excessive quantity of enzymes (Roy et al., 2008; Vahabi et al., 2011) and may help increase the rate of production of nanoparticles. However, the nanoparticles were not as homogenous as those which were produced by A. Fumigates (Bhainsa and D'Souza, 2006) and F. oxysporum (Ahmad et al., 2002). The fungal attribute to produce intracellular nanoparticles is helpful in getting rid of the fungus and its gathered metallic contaminant. A white-rot fungus (Coriolus versicolor) is suggested to provide and accumulate AgNPs extra and intracellularly by manipulating reaction conditions (Sanghi and Verma, 2008). Only a few fungi are considered to have the potential to synthesize gold nanoparticles despite the increasing demand in various fields. The small size of gold nanoparticles causes them to become more reactive and appropriate as compared to the bulk form to be used as precursors for electronics applications and catalysts (Mukherjee et al., 2001; Eustis and El-Sayed, 2006). The synthesis of AuNPs using Verticillium sp. by the biological reduction of $\mathrm{AuCl}_{4}$ localized on the surface of the mycelia (Mukherjee et al., 2001).

Biological synthesis of Platinum nanoparticles (PtNPs) was carried out by the use of fungus Neurospora crassa. It produced single PtNPs (Platinum nanoparticles) intracellularly ranging in size from 4 to $35 \mathrm{~nm}$ in diameter. They may additionally synthesize spherical nano-agglomerates in the range of 20 $110 \mathrm{~nm}$ diameter (Castro et al., 2013). Both biomass and extract of $N$. crassa were used to synthesize PtNPs. The PtNPs synthesized using the $N$. Crassa extract contains single-crystal nano agglomerates (Castro et al., 2011, 2013). PtNPs were also reportedly synthesized extra and intracellularly by F. oxysporum but with sub-optimal quantity when synthesized intracellularly (Riddin et al., 2006). The phytopathogenic fungus F. oxysporum and the endophytic fungus Verticillium sp. had been reported to synthesize magnetite (a common iron oxide) nanoparticles (MaNPs) intracellularly (Bharde et al., 2006).

The use of fungi for nanoparticles synthesis has some benefits over the use of bacteria namely; scaling up and easy downstream processing, the economic status, and an increased surface area provided by the fungal mycelia (Mukherjee et al., 2001). The higher amount of proteins secreted by using fungi should likely increase the productivity of nanoparticle synthesis but safety is compromised since a number of fungi are phytopathogenic and may pose a safety risk (Spadaro and Gullino, 2005). Trichoderma asperellum and Trichoder mareesei are non-pathogenic making them ideal for commercial applications (Nevalainen et al., 1994; Roy et al., 2008; Vahabi et al., 2011). T. reesei is broadly used in animal feed, food, paper, pharmaceuticals, and textile industries (Nevalainen et al., 1994).

\section{Nanoparticle Synthesis Using Yeast}

Yeasts can absorb and accumulate a good quantity of lethal metals from their adjacent areas due to their large surfaces (Bhattacharya and Gupta, 2005; Mandal et al., 2006). Yeast uses a range of detoxification mechanisms to adapt to toxic metals such as bio-precipitation, chelation, extracellular sequestration and bio-sorption. These mechanisms adapted through yeast cells are used during nanoparticle synthesis to form and increase the durability of nanoparticles, giving rise to variation in particle size, particle properties, and location (Hulkoti and Taranath, 2014). The intracellular synthesis of CdS quantum dots turned into confirmed via Candida glabrata when exposed to cadmium salts (Dameron et al., 1989). The growth phase of yeast Schizosaccharomyces pombe cells and the formation of CdS quantum dots are linked together (Kowshik et al., 2002a,b). Torulopsis sp. synthesizes $\mathrm{PbS}$ quantum dots when exposed to $\mathrm{Pb}^{2}$ ions and Pichia jadinii synthesizes $\mathrm{Au}$ nanoparticles intracellularly. The size range of these nanoparticles is from a few nanometers to around $100 \mathrm{~nm}$. The morphological characteristics of these nanoparticles were easily conducted by monitoring the cellular activities and growth of $P$. jadinii during the synthesis 
of the nanoparticle (Gericke and Pinches, 2006a,b). The use of metallic nanoparticles has become vital due to their safety and prospective applications.

\section{Nanoparticles Synthesis Using Cyanobacteria (Blue Green Algae)}

Green and valuable synthetic techniques have attracted great interest in the synthesis of nanoparticles (Sundrarajan and Gowri, 2011). Cyanobacteria strains are an inexpensive eco-friendly tool for nanometal formation. Cyanobacterial technology offers the merits of eco-friendly methods, such as timesaving for large-scale production at ambient temperatures. They grow much faster compared to the plants and could easily be manipulated as needed. Studies on molecular biology and ecology regarding synthesis of nanoparticles offer a great opportunity for efficient development of application-oriented nanoparticles. The common cyanobacterial strains used in nanoparticle biosynthesis vary from unicellular and colonial species. Colonies might form sheets, filamentous, or even hollow balls. They may fix atmospheric nitrogen besides fixing the atmospheric carbon dioxide during photosynthesis. Some strains grow in dark under organotrophic/chemotrophic/lithotrophic conditions offering a wide range of modes of nutrition with normal plants-like photosynthesis. Few strains exhibit symbiotic conditions with lichen (Fungi), bryophytes (Liverworts), gymnosperms (Cycas), and with higher plants (Macrozamia). They require a lesser quantity of chemicals as they are all photoautotrophic and may also grow under the chemo-autotrophic condition in light and dark.

Out of the 30 different strains of cyanobacteria (unicellular, colonial, undifferentiated and differentiated filamentous) studied for the silver nanoparticles biosynthesis, the filamentous heterocystous strain Cylindrospermum stagnale was the best organism synthesizing nanoparticles of 38-40 nm (Husain elal., 2015). In general, the time frame varied from 30 to $360 \mathrm{~h}$, and the size varied from 38 to $88 \mathrm{~nm}$ (Husain et al. 2015). The techniques of synthesis of AgNPs using cyanobacteria Spirulina platensis and Nostoclinckia have been studied (Cepoi et al., 2014). There is a need to understand the optical conditions of the interaction among the biomass and solution containing Ag ions that may allow nanoparticles without biomass degradation at the time of Ag nanoparticle formation (Cepoi et al., 2014; Hamouda et al., 2019). The green synthesized silver nanoparticles via simple biological protocol using Oscillatoria limnetica aqueous extract that had provided both a decreasing and stabilizing agent for the biosynthesis of nanoparticles by suspending the live and washed biomass into the $\mathrm{AgNO}_{3}$ solution and by adding $\mathrm{AgNO}_{3}$ into a cell-free culture liquid (Patel et al., 2015) assessed the selected strains of cyanobacteria for the ability to synthesize AgNPs. Around 14 out of 16 tested strains have been utilized for the AgNPs biosynthesis. Mostly, AgNPs have been formed in the presence of biomass in addition to the cell-free culture media indicating that the Ag-NPs formation technique engages an extracellular compound inclusive of polysaccharide. TEM evaluation revealed that nanoparticles were set in an organic matrix. AgNPs varied in shape and sizes that ranged between 13 and $31 \mathrm{~nm}$, depending upon the organism used (Patel et al., 2015). With the exception of one strain of Cyanobacterium Limnothrix sp., all strains confirmed the antibacterial activity of Ag-NPs (Patel et al., 2015). For the gold nanoparticles green synthesis, Lyngbya majuscula and Spirulina subsalsa were investigated as bioreagents. The cyanobacterial biomass turned purple within $72 \mathrm{~h}$ of incubation at $15 \mathrm{mg} \mathrm{L}-1 \mathrm{Au}^{3+}$ solution, indicating an intracellular reduction of $\mathrm{Au}^{3+}$ to $\mathrm{Au}^{0}$ and subsequent formation of gold nanoparticles. Spirulina subsalsa showed the synthesis of spherical nanoparticles of $\sim 5$ to $\sim 30 \mathrm{~nm}$ in diameter along with very few nanorods. Lyngbya majuscule showed the presence of spherical and hexagonal nanoparticles of $\sim 2$ to $\sim 25 \mathrm{~nm}$ in diameter. The reduction of $\mathrm{Au}^{3+}$ to $\mathrm{Au}^{0}$ was proved by the XRD study. FTIR analysis indicated the presence of protein shells around the gold nanoparticles (Parial and Pal, 2011). The biosynthesis of AgNPs and their antimicrobial property and photocatalytic activity for photodegradation of organic dye were studied by San Keskin et al. (2016). The characterization of synthesized Ag nanoparticles was carried out by UV-Vis spectrophotometer (surface plasmon resonance band at 430 $450 \mathrm{~nm}$ ). The Attenuated Total Reflection Fourier Transform Infrared Spectroscopy (ATR-FTMR) study confirmed the reducing nature of proteins. The Scanning electron microscopy (SEM) and Transmission electron microscopy (TEM) were used to determine the structure of AgNPs and was found to be spherical. The AgNPs showed photocatalytic activity that is photodegradation of organic dye i.e., methylene blue. It was shown that methylene blue was degraded by $\sim 18 \%$ within 4h with biosynthesized AgNPs (San Keskin et al., 2016). The biosynthesis of AgNPs has been efficaciously performed with the use of bloom-forming filamentous undifferentiated cyanobacterium Plectonema boryanum which reacted with solution of $\mathrm{AgNO}_{3}(\sim 560 \mathrm{mg} / \mathrm{L} \mathrm{Ag})$ for up to 28 days at 25$100^{\circ} \mathrm{C}$. The precipitation of spherical AgNPs and octahedral silver platelets (of up to $200 \mathrm{~nm}$ ) in solutions is promoted by interaction of cyanobacteria with $\mathrm{AgNO}_{3}$ Solution. The mechanism of formation of AgNPs via cyanobacteria may involve the metabolic processes in which nitrate is used at $25^{\circ} \mathrm{C}$, and organics are released from the lifeless cyanobacteria at $25-100^{\circ} \mathrm{C}$ (Lengke et al., 2006, 2007). The cyanobacterium Gloeocapsa sp. was an effective strain for nanosilver production (Al-Katib et al., 2015). The extracellular synthesis of AgNPs was initially detected by visual inspection for color changing of the cultured flasks solutions from transparent to brown then black, as well as nanoparticles characterization through UV-Vis spectrophotometer and Fourier Transform Infrared spectroscopy (FTIR) with characteristic surface Plasmon absorption peaks at range $400-450 \mathrm{~nm}$. The FTIR spectrum data in addition confirmed the presence of specific functional groups such as proteins and does have an important role as a capping and stabilizing agent in the biosynthesis of AgNPs (Al-Katib et al., 2015). Cyanobacteria could play an instrumental role as an excellent candidate for nanoparticle biosynthesis.

\section{Nanoparticle Synthesis Using Algae}

Algae are regarded to accumulate heavy metals and may be utilized for the biogenic synthesis of metallic nanoparticles. 
Dried unicellular alga Chlorella vulgaris could synthesize nanoparticles of diverse shapes-tetrahedral, decahedral, and icosahedral accumulated near the surface (Luangpipat et al., 2011). The extract of Chlorella vulgaris produced Ag nanometer scale plates at room temperature. Biosynthesis of $\mathrm{CuFe}_{2} \mathrm{O}_{4} @$ Agnano composite from Chlorella vulgaris combined with ciprofloxacin confirmed promising bactericidal activity toward multidrug resistant Staphylococcus aureus which is a rising global risk (Kahzad and Salehzadeh, 2020). The proteins present in the algal extract perform a primary function as a stabilizing agent, reducing agent, and shape-control modifier (Xie et al., 2007). Sargassum wightii, a marine alga, could also synthesize extracellular $\mathrm{Ag}, \mathrm{Au}$, and $\mathrm{Au} / \mathrm{Ag}$ bimetallic nanoparticles (Govindaraju et al., 2009). Rapid synthesis of extracellular Au nanoparticles with a size from 8 to $12 \mathrm{~nm}$ via S. wightii has been demonstrated by Singaravelu et al. (2007). Several other algae Kappaphycu salvarezii (Rajasulochana et al., 2011), Fucus vesiculosus (Mata et al., 2008), Tetraselmisko chinensis (Senapati et al., 2012), Chondrus crispus, and Spirogyra insignis (Castro et al., 2013) have been reported to synthesize $\mathrm{Au}$ and $\mathrm{Ag}$ nanoparticles (Rajasulochana et al., 2011). By using the living cells of Euglena gracilis microalga which have been grown under either mixotropic (exposed to light and grown in an organic carbon-enriched culture medium) or autotropic condition, the gold nanoparticles synthesized were of true yield, kinetics and colloidal stability (Dahoumane et al., 2016).

\section{Nanoparticle Synthesis Using Plants}

The plants are considered to be more suitable compared to microbes for green synthesis of nanoparticles as they are nonpathogenic and various pathways are thoroughly researched (Figure 4). A wide spectrum of metal nanoparticles has been produced using different plants (Narayanan and Sakthivel, 2011; Iravani and Zolfaghari, 2013; Mittal et al., 2013; Das et al., 2017). These nanoparticles have unique optical, thermal, magnetic, physical, chemical, and electrical properties in comparison to their counterpart bulk material with numerous applications in numerous fields of human interest (Husseiny et al., 2007; Duran and Seabra, 2012). There are various biological entities which are used for AgNPs synthesis (Keat et al., 2015). Jatroa curcas extract results in the production of homogenous $(10-20 \mathrm{~nm})$ AgNPs from $\mathrm{AgNO}_{3}$ salt in $4 \mathrm{~h}$ (Bar et al., 2009). The leaf extracts of Acalypha indica have exhibited the capability to synthesize AgNPs. The size of the AgNPs obtained became extensively homogeneous and ranged from 20 to $30 \mathrm{~nm}$ (Krishnaraj et al., 2009). In another study, Medicago sativa seed exudates were used for the synthesis of AgNPS. The reduction of $\mathrm{Ag}^{+}$happened almost immediately as nanoparticles had been reported within a minute of metal salt exposure and $90 \%$ of $\mathrm{Ag}^{+}$was reduced at $30^{\circ} \mathrm{C}$ in $<50 \mathrm{~min}$. The resulting nanoparticles were flowerlike and/or triangular and spherical with a size range of 5$108 \mathrm{~nm}$ and had a heterogeneous size distribution (Lukman et al. 2010). The leaf extract of Ocimum sanctum can also reduce $\mathrm{Ag}^{+}$resulting in the AgNPs of $3-20 \mathrm{~nm}$ in size

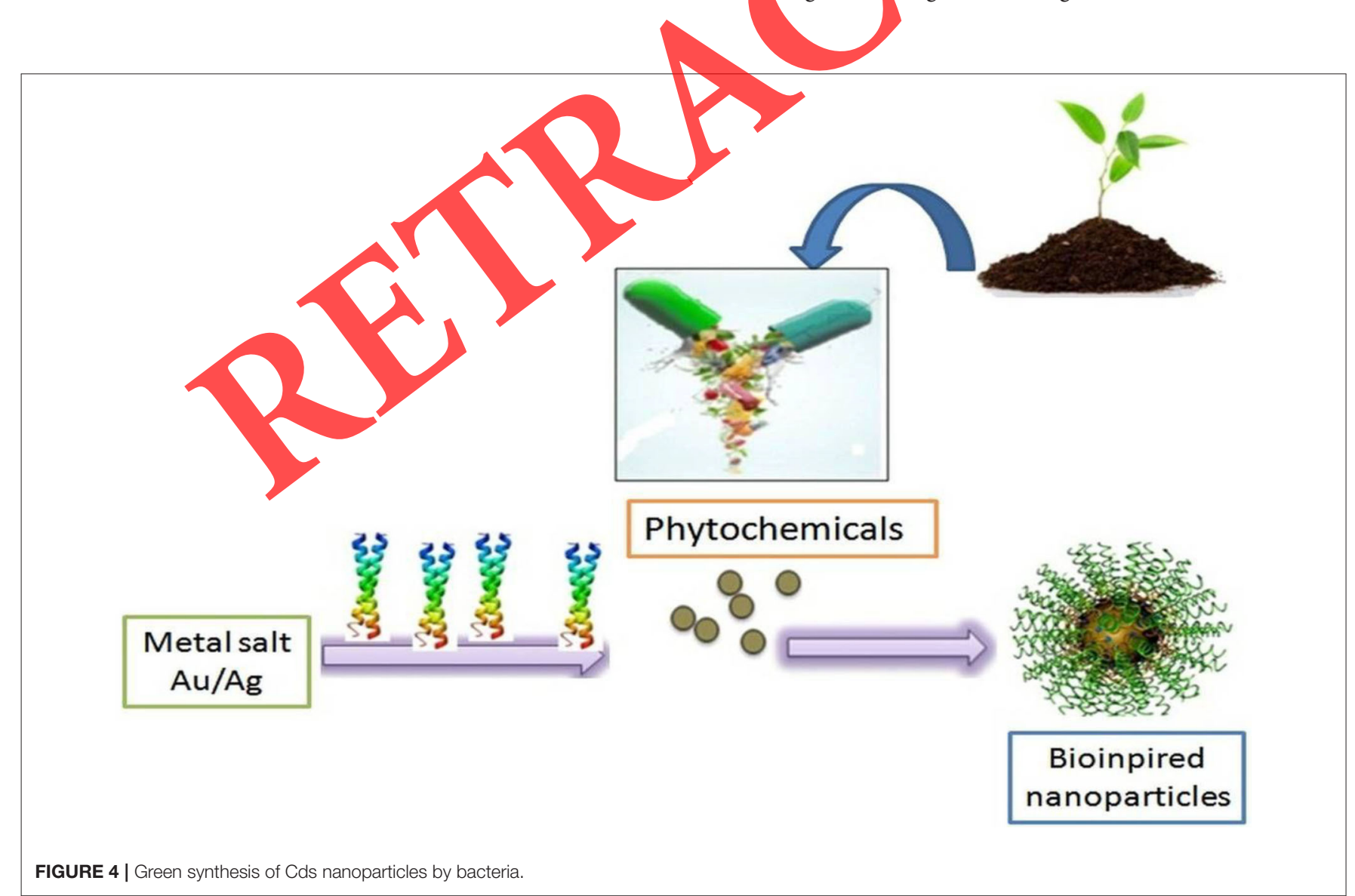


production The particles were spherical and stabilized by the way of a component of the leaf broth (Koduru et al., 2011). Terminalia chebula fruit extract has been used to promptly produce Ag nanoparticles (Jebakumar Immanuel Edison and Sethuraman, 2012). Eucalyptus macrocarpa leaf extract produced $\mathrm{Ag}$ nanoparticles of cubic shape ranging in size from 50 to $200 \mathrm{~nm}$ (Poinern et al., 2013); spherical gold nanoparticles of around $20 \mathrm{~nm}$ by Nyctanthes arbor tristis (night jasmine) flower extract (Das et al., 2011); leaf extract from Coriandrum sativum (coriander) leaf extract produce $\mathrm{Ag}$ and $\mathrm{Au}$ nanoparticles of 7-58 nm (Mittal et al., 2013). Phyllanthin extracted from the plant Phyllanthus amarus may be used to produce both gold and silver nanoparticles. This study is unique for the use of single constituent of a plant extract to synthesize metallic nanoparticles in comparison to different investigations wherein the whole plant was used (Kasthuri et al., 2008). The shape and size of nanoparticles produced had been affected by the concentration of phyllanthin used. Low concentrations of phyllanthin resulted in the triangular and hexagonal AuNPs formation, whereas higher concentrations produced increased spherical NPs (Kasthuri et al., 2008). Plant derived polysaccharides and phytochemicals nanoparticle (Park et al., 2011), soluble starch (Raveendran et al., 2003), cellulose (Cai et al., 2009), dextran (Ma et al., 2005), chitosan (Laudenslager et al., 2008), alginic acid (Saha et al., 2009), and hyaluronic acid (Kemp et al., 2009) may be harnessed and studied for the synthesis of silver and gold nanoparticles successfully. These compounds offer benefits of using less toxic chemical compounds and render capability to create nanocomposites with different metals. The incubation of the extract from lemon-grass plant, Cymbopogon flexuosus, with gold tetrachloride solution resulted in the formation of a unique type of liquid-like nanotriangles by the aggregation of spherical AuNPs, the surface of which forms a complex with the aldehydes and/or ketones present in the plant extract, contributing to the fluidity (Sangaru et al., 2004). The leaf broth of Azadirachta indica, forms a complex when dealing with the salts of silver, gold, and then both metallic ions concurrently produced silver, gold, and bimetallie silver-gold NPs. The rate of formation of nanoparticles became faster having attained the plateau in 2h. The stability of NPs was attributed to the terpenoid and flavanone components of the leaf (Sangaru et al., 2004). Phytochemically reduced NiO NPs with garlic and ginger add on to the increased bactericidal activity toward multiple drug resistant Staphylococcus aureus which may address drug resistance issues to an extent (Haider et al., 2020).

Alloying $\mathrm{Ag}$ and $\mathrm{Au}$ has brought about the formation of bimetallic nanoparticles. Their production entails the competitive reduction between two aqueous solutions having one of a kind of metallic ion precursor used together with a plant extract. The Ag-Au nanoparticle, the core-shell structure is manufactured from $\mathrm{Au}$ due to its larger reduction potential, and $\mathrm{Ag}$ ions are reduced and form a shell with $\mathrm{Ag}$ coalescing on the core. Few plants have been efficiently used to synthesize Ag-Au bimetallic nanoparticles like Azadirachta indica (Sangaru et al., 2004), Anacardium occidentale (Sheny et al., 2011), Swieteni amahagony (Mondal et al., 2010), and cruciferous vegetable extracts (Jacob et al., 2012).
Extracts from various plants have been used to synthesize nanoparticles of copper $(\mathrm{Cu})$ and copper oxide $(\mathrm{CuO}) . \mathrm{Cu}$ nanoparticles varying from 40 to $100 \mathrm{~nm}$ in size were synthesized from Magnolia kobus leaf extract (Lee et al., 2013) and from Syzygium aromaticum (Clove) (Subhankari and Nayak, 2013) showing spherical to granular shape with $40 \mathrm{~nm}$ of an average particle size. The Latex from the stem of Euphorbia nivulia (Common milk hedge) was used to synthesize an important class of $\mathrm{Cu}$ nanoparticles stabilized and coated through terpenoids and peptides of the latex (Valodkar et al., 2011a) and synthesis of a notably stable spherical nanoparticles of $\mathrm{CuO}$ was confirmed from Sterculia urens (Karaya gum) with a particle size of $4.8 \mathrm{~nm}$ (Padil and Cernik, 2013).

The synthesis of the first platinum nanoparticles was demonstrated with the help of Song et al. (2009b) Diospyros kaki (Persimmon) leaf extract and carboxylic acids, amines, alcohols. Ketones present in the leaf extract act as a functional group for the reduction of Pt ions. There was 90\% reduction of Pt ions into nanoparticles in $\approx 2.5 \mathrm{~h}$. The possibility of an enzyme mediated process was ruled out due to the temperature of execution of the experiment $\left(95^{\circ} \mathrm{C}\right)$ which is high enough to denature proteins. Palladium nanoparticles were synthesized using the extract of Cinnamon zeylanicum bark (Sathishkumar et al., 2009a b) and Annona squamosa (custard apple) peel extract for the synthesis of Pd nanoparticles of size $75-85 \mathrm{~nm}$ (Roopan et al., 2012). Nanoparticles with a mean size of $15 \mathrm{~nm}$ had been synthesized from the leaf extract of soybean (Glycine max) (Petla et al., 2012). The extracts from commonly available Camellia sinensis (Tea) and Coffe aarabica (Coffee) have been utilized to produce nanoparticles of palladium of sizes ranging from 20 to $60 \mathrm{~nm}$ with faced centered cubic crystal symmetry (Petla et al., 2012). Furthermore, when an extract of Gardenia jasminoides (Cape jasmine) is used to synthesize nanoparticles of palladium the antioxidants (geniposide, chlorogenic acid, crocins, and crocetin) present in the extracts acts as stabilizing and reducing agents (Jia et al., 2009). Other plants like Ocimum sanctum leaf extract (Holy basil) (Soundarrajan et al., 2011), plant wood nanomaterials (Lin et al., 2011) and lignin from red pine (Pinus resinosa) were used for the synthesis of nanoparticles of platinum and palladium (Coccia et al., 2012).

Nanoparticles of spherical size and ranging in size from 100 to $150 \mathrm{~nm}$ from metal oxide which includes titanium dioxide $\left(\mathrm{TiO}_{2}\right)$ were synthesized efficaciously using numerous plant extracts viz. Annona squamosa peel (Roopan et al., 2012), Cocos nucifera coir (Roopan et al., 2013), Nyctanthes arbor-tristis leaf extracts (Sundrarajan and Gowri, 2011), Psidium guajava (Thirunavukkarasu et al., 2013), Eclipta prostrata (Rajakumar et al., 2011; Zahir et al., 2015), and Catharanthus roseus (Kanayairam et al., 2011). Spherical shaped zinc oxide (ZnO) nanoparticles were obtained using the latex of Calotropis procera (Singh, 2011), Aloe vera (Duran and Seabra, 2012), Physalisalke kengi (Sangeetha et al., 2011), and Sedum alfredii (Qu et al., $2011 \mathrm{a}, \mathrm{b})$. Biogenic Indium oxide $\left(\operatorname{In}_{2} \mathrm{O}_{3}\right)$ spherical nanoparticles were synthesized with a variable size range from 5 to $50 \mathrm{~nm}$ by using leaf extracts from Aloe vera (Aloe barbadensis) (Laokula et al., 2008). 
Iron $(\mathrm{Fe})$ nanoparticles were synthesized by the use of green chemistry methods including the aqueous Sorghum bicolor bran extracts (Njagi et al., 2011) and leaf extracts of Azadirachta indica (Pattanayak and Nayak, 2013), Euphorbia milii, Tridax procumbens, Tinospora cordifolia, Datura innoxia, Calotropis procera, and Cymbopogon citratus (Shah et al., 2014). The latex from Jatropha curcas has been used to synthesize spherical $\mathrm{Pb}$ nanoparticles of sizes from 10 to $12.5 \mathrm{~nm}$ (Joglekar et al., 2011). Synthesis of metallic nanoparticles includes the use of the extracts of plant parts or whole plant extracts. Also, metallic nanoparticles may be synthesized inside living plants and a novel approach for the synthesis of PdNPs by the use of Arabidopsis thaliana was reportedly developed (Parker et al., 2014) by growing the plant in the usual growth medium, and medium was then replaced with potassium tetrachloropalladate $\left(\mathrm{K}_{2} \mathrm{PdCl}_{4}\right)$ followed by the incubation for $24 \mathrm{~h}$ in the salt solution. PdNPs of $2-4 \mathrm{~nm}$ were produced as visualized by transmission electron microscope. These biologically synthesized PdNPs had been utilized in Suzuki-Miyaura coupling reactions with better catalytic activity as compared to the commercially available PdNPs (Parker et al., 2014). The Alfalfa plant seeds were grown with various concentrations of $\mathrm{K}\left(\mathrm{AuCl}_{4}\right)$ for 2 weeks for the formation of AuNP nanoparticles (Gardea-Torresdey et al., 2002). The time taken for the synthesis of nanoparticles via this method exceeds 2 weeks, limiting its commercial feasibility. However, if production time is reduced, it might be a great strategy for creating a cheap green method for synthesizing nanoparticles.

\section{Nanoparticle Synthesis Using Viruses}

Quantum dots were synthesized by using viruses over the last decade (Dameron et al., 1989; Lee et al., 2002; Mao et al., 2003) for the synthesis of nanomaterials. The outer capsid protein present on the virus offers an attractive function in the synthesis of nanoparticles by supplying a highly reactive surface interacting with metallic ions (Makarov et al, 2014). Tobacco mosaic virus (TMV) has $\sim 2,130$ capsid proteins masking its surface. These proteins act as notch attachments for the material to deposit (Royston et al., 2008; jabali et al., 2010; Górzny et al., 2010; Kobayashi et al, 2012) or may be used to synthesize the three-dimensional vessels for multiple applications in the pharmaceutical industry. The addition of $\mathrm{Ag}$ or $\mathrm{Au}$ salts to low concentrations of TMV prior to including plant extracts of Nicotiana benthamiana (Round-leaved native tobacco) or Hordeum vulgare (Barley) showed a decrease in the size of the synthesized nanoparticles. Additionally it accelerated their numbers as compared to those having no viral supplement (Love et al., 2014) showing relatively small free nanoparticles formation at higher TMV concentrations. TMV also served as a bio-template to form nanowires by using metallization. The unexplored potential of viruses in the manufacture of nanometer scale structures of different varieties have been reported elsewhere (Shenton et al., 1999; Merzlyak and Lee, 2006). They deliver inorganic substances such as cadmium sulfide $(\mathrm{CdS})$, silicon dioxide $\left(\mathrm{SiO}_{2}\right)$, zinc sulfide $(\mathrm{ZnS})$, and iron oxide $\left(\mathrm{Fe}_{2} \mathrm{O}_{3}\right)$. Semiconductor substances such as $\mathrm{CdS}$ and $\mathrm{ZnS}$ are utilized in electronic goods and therefore hold importance in the electronics industry.
TABLE 1 | Factors affecting biological synthesis of metal nanoparticles.

\begin{tabular}{|c|c|c|c|}
\hline S. No & Factors & $\begin{array}{l}\text { Influence on biological } \\
\text { synthesis of metal } \\
\text { nanoparticles }\end{array}$ & References \\
\hline 1. & $\mathrm{pH}$ & $\begin{array}{l}\text { Size and shape of the } \\
\text { synthesized nanoparticle }\end{array}$ & $\begin{array}{l}\text { Dubey et al., 2010; } \\
\text { Sathishkumar } \\
\text { et al., } 2010\end{array}$ \\
\hline 2. & $\begin{array}{l}\text { Reactant } \\
\text { concentration }\end{array}$ & $\begin{array}{l}\text { Shape of the synthesized } \\
\text { nanoparticles }\end{array}$ & $\begin{array}{l}\text { Chandran et al., } \\
2006\end{array}$ \\
\hline 3. & Reaction time & $\begin{array}{l}\text { Size and shape of the } \\
\text { synthesized nanoparticle }\end{array}$ & Tc et al., 2011 \\
\hline 4. & $\begin{array}{l}\text { Reaction } \\
\text { temperature }\end{array}$ & $\begin{array}{l}\text { Size, shape, yield and stability of } \\
\text { the synthesized nanoparticle }\end{array}$ & $\begin{array}{l}\text { Song et al., 2009a; } \\
\text { Sathishkumar } \\
\text { et al., } 2010\end{array}$ \\
\hline
\end{tabular}

\section{FACTORS AFFECTING BIOLOGICAL SYNTHESIS OF METAL NANOPARTICLES}

The morphological characteristics of nanoparticles can be manipulated by means of various parameters viz. reaction time, reactant concentrations, $\mathrm{pH}$, and temperature (Table 1). Such parameters are crucial to understand the effect of environmental factors for the synthesis of NP as they may play an important role during the optimization of metallic NPs synthesis by biological means.

\section{$\mathrm{pH}$}

eaction medium $\mathrm{pH}$ plays an critical role in the formation of nanoparticles (Gardea-Torresdey et al., 1999). Size and shape of nanoparticles vary with the $\mathrm{pH}$ of the medium, and large sized nanoparticles are produced in acidic $\mathrm{pH}$ (Dubey et al., 2010; Sathishkumar et al., 2010). The rod-shaped gold nanoparticles were synthesized by using biomass of Avena sativa (Oat) resulting in the size range from 25 to $85 \mathrm{~nm}$ at $\mathrm{pH} 2$ which was comparatively smaller $(5-20 \mathrm{~nm})$ at $\mathrm{pH} 3$ and 4 (Armendariz et al., 2004). Further, accessibility of functional groups for particle nucleation in the extract was better at $\mathrm{pH} 3$ or 4 as compared to the $\mathrm{pH} 2$ as fewer functional groups were available prompting particle aggregation to form larger Au nanoparticles. An increased number of spherical Ag nanoparticles were synthesized in Cinnamon zeylanicum bark extract at higher $\mathrm{pH}(\mathrm{pH}>5)$ (Kumar and Yadav, 2009). A slight increase was observed in particle size at higher $\mathrm{pH}$ when Cinnamon zeylanicum bark extract was used for the synthesis of palladium (Pd) nanoparticles, and particle size was estimated from 15 to $20 \mathrm{~nm}$ at $\mathrm{pH}<5$, and $20-25 \mathrm{~nm}$ at the higher $\mathrm{pH}$ (Kumar and Yadav, 2009).

\section{Reactant Concentration}

The formation of metallic nanoparticles is affected by the concentration of biomolecules present in the extract. The shape of the biosynthesized $\mathrm{Au}$ and $\mathrm{Ag}$ nanoparticles by using the sundried Cinnamomum camphora (camphor) leaf extract affected by the amount of biomass in the reaction medium (Huang et al., 2007). Exposure of the precursor chloroauric acid to 
growing concentrations of the extract resulted in the synthesis of spherical nanoparticles instead of triangular. A change in the ratio of spherical nanoparticles to triangular plates in the reaction medium having chloroaurate ions due to the presence of carbonyl compounds in the extract was observed when treated with varying concentrations of Aloe vera leaf extract (Chandran et al., 2006). Nanoparticle size can be modulated between 50 and $350 \mathrm{~nm}$ by using different extract concentrations (Chandran et al., 2006). Spherical, triangular, hexagonal, and decahedral shapes of AgNPs were produced by varying the concentration of Plectranthu samboinicus leaf extract in the reaction medium (Narayanan and Sakthivel, 2010). An increase in the variety of Ag nanoparticles was observed with increasing concentration of Cinnamon zeylanicum bark extract (Kumar and Yadav, 2009). The extracellular (Agnihotri et al., 2009) and intracellular synthesis (Pimprikar et al., 2009) of Au nanoparticles was affected by biomass and Au salt concentration using marine yeast, Yarrowia lipolytica. An increased Au salt concentration produced both nanoscale spheres and plates. In another study, a silver-tolerant yeast strain MKY3 synthesized spherical Ag nanoparticles extra-cellularly with the size ranging from 2 to $5 \mathrm{~nm}$ (Kowshik et al., 2003).

\section{Reaction Time}

The reaction time plays an important role for synthesizing nanoparticles (Ahmad, 2012). A rapid color change was observed within 2 min when Anana scomosus (Pineapple) extract was used for AgNPs synthesis, and aqueous $\mathrm{AgNO}_{3}$ solution was rapidly decreased, forming nanoparticles within $2 \mathrm{~min}$. The reaction continued for up to $5 \mathrm{~min}$ and then there was a slight color change. The shape of synthesized nanoparticles was spherical with a mean size of $12 \mathrm{~nm}$ (Ahmad, 2012). Chenopodium album leaf extract was used for the biogenic production of $\mathrm{Ag}$ and $\mathrm{Au}$ nanoparticles. The nanoparticles were formed within $15 \mathrm{~min}$ of the reaction and the reaction continued over a period of $2 \mathrm{~h}$ and very few nanoparticles with larger size were synthesized (Bwivedi and Gopal, 2010). Change in the particle size (ranging 10-35 nm) was observed when reaction time was increased from $30 \mathrm{~min}$ to $4 \mathrm{~h}$ using Azadirachta indica leaf extract and $\mathrm{AgNO}_{3}$ (Tc et al., 2011).

\section{Reaction Temperature}

The reaction temperature is a critical component which plays a key role in determining the shape, size, and yield of synthesized nanoparticles using plants (Song et al., 2009a; Sathishkumar et al., 2010). The peel extract of Citrus sinensis (sweet orange) produced particles with an average size of around $35 \mathrm{~nm}$ at $25^{\circ} \mathrm{C}$. The average size of the nanoparticles decreased to $10 \mathrm{~nm}$ with the rise in the reaction temperature to $60^{\circ} \mathrm{C}$ (Kaviya et al., 2011). The stable Ag nanoparticles were synthesized by Diospyros kaki (persimmon) leaf extract at the reaction temperature varying from 25 to $95^{\circ} \mathrm{C}$ (Song et al., 2009b). The variation in the temperature of reaction conditions for the synthesis of $\mathrm{Au}$ nanoparticles using Avena sativa (oat) biomass ended in modifications in the shape and size of the nanoparticles produced (Armendariz et al., 2004). A higher temperature supports an increased rate of formation of $\mathrm{Au}$ nanoparticles. The spherical
$\mathrm{Au}$ nanoparticles were predominantly formed at the lower temperature whereas at higher temperatures rod-like and platelike nanoparticles were formed (Gericke and Pinches, 2006a,b). The reaction rate and particle formation rate increased with the increase in the reaction temperature. The particle conversion rate steadily increased and average particle size saw a decrease with the rise in the reaction temperature to $60^{\circ} \mathrm{C}$.

The extracellularly produced PtNPs amount was reported to be $5.66 \mathrm{mg} \mathrm{l}^{-1}$ (Riddin et al., 2006), with the variation in the temperature that affects production rates of the PtNPs. The slight change in $\mathrm{pH}$ from the standard inhibits the PtNPs formation (Riddin et al., 2006).

\section{APPLICATIONS OF METALLIC NANOPARTICLES SYNTHESIZED BY GREEN TECHNOLOGY}

Nanoparticles have wide applieations in both biomedical and physicochemical fields. They may be used for drug delivery, biosensing, bio-imaging, and biomolecular recognition (Figure 5) in bio-medical research. Such nanoparticles are integrated in various materials of everyday use which includes cosmetics, toothpaste, deodorants, water purification systems, and humidifiers due to their anti-microbial properties (Baker et al., 2005). They have an important role to play in agriculture technology such as detection and abatement of plant diseases and minimizing nutrient leaching to increase the crop yield. They are also used in solar and oxide batteries for energy storage.

\section{Gold and Silver Nanoparticles}

The variation in shape, size, and surface properties of $\mathrm{Au}$ nanoparticles (Wang et al., 2005; Ghosh and Pal, 2007; Cai et al., 2008; Alexandridis, 2011; Shivaji et al., 2014) makes them very beneficial for their potential applications within the area of biosensors (Chan and Nie, 1998; Kreibig and Vollmer, 2013), hyperthermia therapy (Huang et al., 2006), delivery systems for therapeutic drugs and genetic materials (Paciotti et al., 2004), as well as anti-bacterial drugs (Sondi and Salopek-Sondi, 2004; Hsiao et al., 2006). Gold nanoparticles from Sesbaniadrum mondii (rattlebush) have shown the catalytic activity that may be beneficial in the reduction of aromatic nitro compounds in waste decontamination.

The rise in antibiotic resistance among pathogenic bacteria has highlighted the antibacterial properties of nanoparticles and their ability to be used as new medical tools. The antimicrobial activity of Ag is widely known and is used in multiple medical preparations against pathogens (Sondi and Salopek-Sondi, 2004; Kumar and Yadav, 2009; Sotiriou and Pratsinis, 2011). The antibacterial properties of AbNPs have allowed for their extensive use in food storage, the health industry, textile coatings and several environmental applications. Silver nanoparticles synthesized by the use of Tridax procumbens (tridax daisy) extract have robust antibacterial activity toward Escherichia coli, Shigella dysenteriae, and Vibrio cholera (Dhanalakshmi and Rajendran, 2012). Silver nanoparticles obtained by using Pinusthun bergii (Japaneseblack pine) cone extracts exhibit antibacterial activity 


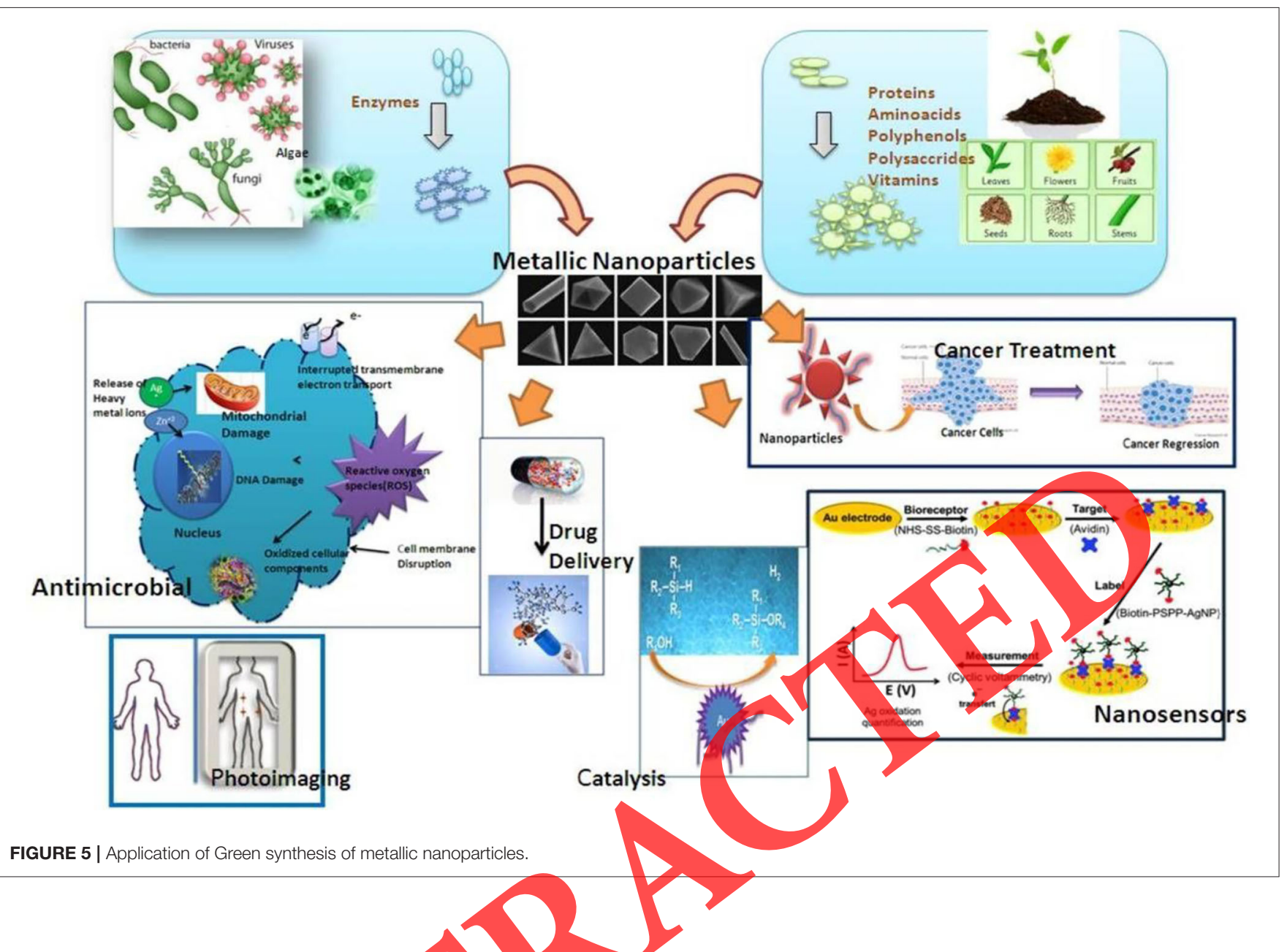

against diverse Gram-negative and Gram-positive agricultural pathogens (Velmurugan et al., 2012), and the antifungal effect of Ag nanoparticles has been confirmed (Vivek et al., 2011). Their utility as antifungal agents is found to be safer as compared to the conventional fungicides (Park et al, 2011). Ag nanoparticles interact closely with the bacterial cell membrane due to their high surface area to volume ratio as well as size (Chen and Schluesener, 2008). Recent antimicrobial studies of Ag nanoparticles have shown that they can cause significant membrane damage and DNA toxicity via bio-sorption and cellular uptake (Brayner et al., 2006; Simon-Deckers et al., 2009). AgNPs are already in-use as antimicrobial agents in many commercially available medical and consumer goods. Despite decades of its use, it is important to note that the evidence of the silver toxicity is not yet fully explored. Their applications have been discovered both in the field of medicine and home remedies. Silver sulfadiazine creams are often used to prevent burn site infection and some companies have also built silver into their washing machines. Presently, silver seems be a part of many consumer products such as computer keyboards, acne creams, and clothing (e.g., socks and athletic wear) that protects the wearer from emitting body odor further to deodorizing sprays. A range of organizations that offer accreditation like US-FDA, US-EPA, Korea's Testing, SIAA of Japan and Research Institute for Chemical Industry and FITI Testing and Research Institute have approved products containing silver nanoparticles (Veeraputhiran, 2013). The silver nanoparticles also display an anti-tumorigenic ability due to their cytotoxic activity against various tumor cells. The growth and survival of HeLa cells were inhibited by the silver nanoparticles synthesized from Iresine herbstii (Herbst's bloodleaf). AgNPs produced by latex extracts of Euphorbia nivulia (leafy milk hedge) exhibited toxicity toward the human lung cancer cells (A549) (Valodkar et al., 2011b). Nerium oleander (oleander) extracted silver nanoparticle displayed robust larvicidal activity against malaria vector larvae (Suganya et al., 2013), as optical sensors that form small molecule adsorbates (McFarland and Duyne, 2003), as selective and sensitive nanoscale affinity biosensors to investigate the transport across the membrane of living microbial cells ( $P$. aeruginosa) in real time (Xu et al., 2004). Silver nanoparticles and their composites demonstrate better catalytic activities in dye reduction and their elimination (Kundu et al., 2002; Mallick et al., 2006).

\section{Copper and Copper Oxide Nanoparticles}

The nanoparticles of $\mathrm{CuO}$ display anti-oxidant, anti-bacterial, and antimicrobial activity against common pathogenic strains such as Escherichia coli and Staphylococcus aureus and are shown to have tremendous application potential (Heinlaan et al., 2008; 
Das et al., 2012; Padil and Cernik, 2013). Cu nanoparticles have antibacterial potential against common pathogenic bacteria Escherichia coli (Lee et al., 2011). They have functional decontaminating properties against several infectious microorganisms with the potential to be used as bactericidal material (Akhavan and Ghaderi, 2010; Hassan et al., 2012; Subhankari and Nayak, 2013). The $\mathrm{Cu}$ nanoparticles synthesized by stem latex of Euphorbia nivulia were seen toxic to human lung cancer cells (A549) (Valodkar et al., 2011c) surfacing the their potential application in the field of cancer therapy.

\section{Palladium and Platinum Nanoparticles}

The catalytic activity of platinum nanoparticles extracted from Ocimum sanctum (Holy basil) for the electrolysis of water to produce hydrogen fuel elements has been studied (Soundarrajan et al., 2011). A few Pt nanoparticle based catalysts show elevated activity for the electro-oxidation of formic acid used for the cleaning of surroundings (Waszczuk et al., 2002).

\section{Titanium Dioxide and Zinc Oxide Nanoparticles}

$\mathrm{TiO}_{2}$ suspensions have been explored successfully for both adulticidal and larvicidal properties against Hippobosca maculate (hematophagous fly) and Bovicolaovis (sheep louse) (Kanayairam et al., 2011). $\mathrm{TiO}_{2}$ nanoparticles synthesized from the extract of Psidium guajava confirmed the effective antibacterial activity against Aeromona shydrophila, Escherichia coli, Proteus mirabilis, Pseudomonas aeruginosa, and Staphylococcus aureus, pathogens with strong antioxidant behaviors (Heinlaan et al., 2008; Thirunavukkarasu et al., 2013). $\mathrm{TiO}_{2}$ oxide nanoparticles have shown applications in the biomedical industry, disinfection of waste water, and beauty products. $\mathrm{ZnO}$ nanoparticles additionally possess antibacterial activity that was used in waste water treatments and food packaging (Espitia et al., 2012). Biogenie $\mathrm{ZnO}$ nanoparticles can be used as a drug delivery vehicle for doxorubicin (Vimala et al., 2013) The nanoparticles of magnetite were used in biomedical applications such as magnetic resonance imaging (Sun and Zeng, 2002; You et al., 2013) and oscillation

\section{REFERENCES}

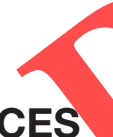

Agnihotri, M., Joshi, S., Kumar, A., Zinjarde, S., and Kulkarni, S. (2009). Biosynthesis of gold nanoparticles by the tropical marine yeast Yarrowia lipolytica NCIM 3589. Mater. Lett. 63, 1231-1234. doi: 10.1016/j.matlet.2009.02.042

Ahmad, A., Mukherjee, P., Mandal, D., Senapati, S., Khan, M. I., Kumar, R., et al. (2002). Enzyme mediated extracellular synthesis of CdS nanoparticles by the fungus, Fusarium oxysporum. J. Am. Chem. Soc. 124, 12108-12109. doi: $10.1021 /$ ja027296o

Ahmad, A., Senapati, S., Islam Khan, M., Kumar, R., Ramani, R., Srinivas, V., et al. (2003b). Intracellular synthesis of gold nanoparticles by a novel alkalotolerant actinomycete, Rhodococcus species. Nanotechnology 14:824. doi: 10.1088/0957-4484/14/7/323

Ahmad, A., Senapati, S., Khan, M., Kumar, R., and Sastry, M. (2005). Extra/intracellular biosynthesis of gold nanoparticles by an alkalotolerant fungus, Trichothecium sp. J. Biomed. Nanotechnol. 1, 47-53. doi: 10.1166/jbn.2005.012

Ahmad, A., Senapati, S., Khan, M. I., Kumar, R., and Sastry, M. (2003a). Extracellular biosynthesis of monodisperse gold nanoparticles by a novel damping and position sensing (Thapa et al., 2004). Furthermore, afore-mentioned NPs have many non-medical applications that include magnetic recording devices.

\section{CONCLUSION AND FUTURE PERSPECTIVE}

Green synthesis technology presents a clean, non-toxic and ecofriendly technique for the synthesis of metallic nanoparticles and is of enormous interest due to economic prospects and feasibility. However, protocols need to be modified further for making these methods cost-effective and comparable with traditional methods for the large-scale production of nanoparticles. Improvement of reliable and eco-friendly processes for the synthesis of metallic nanoparticles is a significant step in the field of applied nanotechnology. Further, most of these strategies are still under the developmental stage and challenges need to be taken care of. These encompass stability and aggregation of nanoparticles, managing the crystal growth, morphology and size. The separation and purification of nanoparticles is another vital parameter which needs to be explored further. Metal nanoparticles produced by the plants and/or plant extracts are more stable as compared to those produced through different organisms. Genetically modified organisms (GMO) have tremendous capability to optimize for generating a greater quantity of proteins, enzymes, and biomolecules required for the biosynthesis and stabilization of nanoparticles. We believe genetic change to enhance the metal tolerance and accumulation capacity is the future approach to enhance the production of metal nanoparticles by adopting the "green synthesis" approach.

\section{AUTHOR CONTRIBUTIONS}

DZ and G-wZ conceived the idea, designed study, executed, and wrote the paper. X-lM, YG, HH, and G-wZ helped during formulation of this article and approved. All authors contributed to the article and approved the submitted version.

extremophilic actinomycete, Thermomonospora sp. Langmuir 19, 3550-3553 doi: $10.1021 / \mathrm{la} 026772 \mathrm{l}$

Ahmad, N. (2012). Green synthesis of silver nanoparticles using extracts of Ananas comosus. Green Sustain. Chem. 2, 141-147. doi: 10.4236/gsc.2012.24020

Akhavan, O., and Ghaderi, E. (2010). Cu and $\mathrm{CuO}$ nanoparticles immobilized by silica thin films as antibacterial materials and photocatalysts. Surf. Coat. Technol. 205, 219-223. doi: 10.1016/j.surfcoat.2010.06.036

Alexandridis, P. (2011). Gold nanoparticle synthesis, morphology control, and stabilization facilitated by functional polymers. Chem. Eng. Technol. 34, 15-28. doi: 10.1002/ceat.201000335

Aljabali, A., Barclay, J., Lomonossoff, G., and Evans, D. (2010). Virus templated metallic nanoparticles. Nanoscale 2, 2596-2600. doi: 10.1039/c0nr00525h

Al-Katib, M., Al-Shahri, Y., and Al-Niemi, A. (2015). Biosynthesis of silver nanoparticles by cyanobacterium Gloeocapsa sp. Int. J. Enhanced Res. Sci. Technol. Eng. 4, 60-73.

Armendariz, V., Herrera, I., Peralta-Videa, J., Yacaman, M., Troiani, H., Santiago, P., et al. (2004). Size controlled gold nanoparticle formation by avena sativa biomass: use of plants in nanobiotechnology. J. Nanoparticle Res. 6, 377-382. doi: 10.1007/s11051-004-0741-4 
Baco-Carles, V., Datas, L., and Tailhades, P. (2011). Copper nanoparticles prepared from oxalic precursors. ISRN Nanotechnol. 2011:729594. doi: $10.5402 / 2011 / 729594$

Baker, C., Pradhan, A., Pakstis, L., Pochan, D., and Shah, S. (2005). Synthesis and antibacterial properties of silver nanoparticles. J. Nanosci. Nanotechnol. 5, 244-249. doi: 10.1166/jnn.2005.034

Bar, H., Bhui, D., Sahoo, G., Sarkar, P., De, S., and Misra, A. (2009). Green synthesis of silver nanoparticles using latex of Jatropha curcas. Colloids Surf. A Physicochem. Eng. Asp. 339, 134-139. doi: 10.1016/j.colsurfa.2009.02.008

Bhainsa, K., and D'Souza, S. (2006). Extracellular biosynthesis of silver nanoparticles using the fungus Aspergillus fumigatus. Colloids Surf. B Biointerfaces 47, 160-164. doi: 10.1016/j.colsurfb.2005.11.026

Bharde, A., Rautaray, D., Bansal, V., Ahmad, A., Sarkar, I., Yusuf, S., et al. (2006). Extracellular biosynthesis of magnetite using fungi. Small 2, 135-141. doi: $10.1002 /$ smll.200500180

Bhattacharya, D., and Gupta, R. (2005). Nanotechnology and potential of microorganisms. Crit. Rev. Biotechnol. 25, 199-204. doi: $10.1080 / 07388550500361994$

Bisen, P., Gour, R., Jain, R., Dev, A., and Sengupta, L. (1996). VAM colonization in tree species planted in $\mathrm{Cu}, \mathrm{Al}$, and coal mines of Madhya Pradesh with special reference to glomus mosseae. Mycorrhiza News 8, 9-11.

Bisen, P. S., Shukla, H. D., Gupta, A., and Bagchi, S. N. (1987). Preliminary characterization of a novel synechococcus isolate showing mercury, cadmium and lead tolerance. Environ. Technol. Lett. 8, 427-432. doi: 10.1080/09593338709384501

Brayner, R., Ferrari-Iliou, R., Brivois, N., Djediat, S., Benedetti, M. F., and Fiévet, F. (2006). Toxicological impact studies based on Escherichia coli bacteria in ultrafine $\mathrm{ZnO}$ nanoparticles colloidal medium. Nano Lett. 6, 66-870. doi: $10.1021 / \mathrm{nl} 052326 \mathrm{~h}$

Cai, J., Kimura, S., Wada, M., and Kuga, S. (2009). Nanoporous cellulose as metal nanoparticles support. Biomacromolecules 10, 87-94. doi: 10.1021/bm800919e

Cai, W., Gao, T., Hong, H., and Sun, J. (2008). Applications of gold nanoparticles in cancer nanotechnology. Nanotechnol. Sci. Appl. 1, 17-32. doi: $10.2147 /$ NSA.S3788

Castro, L., Blázquez, M. L., Muñoz, J., González, F., and Ballester, A. (2013). Biological synthesis of metallic nanoparticles using algae. IET Nanobiotechnol. 7, 109-116. doi: 10.1049/iet-nbt.2012.0041

Castro, L., Blázquez, M. L., Muñoz, J., González, F., García-Balboa, C., and Ballester, A. (2011). Biosynthesis of gold nanowires using sugar beet pulp. Process Biochem. 46, 1076-1082. doi: 10.1016/j.procbio.2011.01.025

Cepoi, L., Ludmila, R., Chiriac, T., Valuta, A., Zinicorscaia, I., Duca, G., et al. (2014). Biochemical changes in cyanobacteria during the synthesis of flver nanoparticles. Can. J. Microbiol. 61, 1-9 doi: 10.1139/cjm-2014-0450

Chan, W. C. W., and Nie, S. (1998). Quantum dot bioconjugates for ultrasensitive nonisotopic detection. Science 281, 2016-2018. doi: $10.1126 /$ science.281.5385.2016

Chandran, S., Chaudhary, M., Pasricha, R., Ahmad, A., and Sastry, M. (2006). Synthesis of gold nanotriangles and silver nanoparticles using Aloe vera plant extract. Biotechnol. Prog. 22, 577-583. doi: 10.1021/bp0501423

Chen, X., and Schluesener, H (2008). Nanosilver: a nanoproduct in medical application. Toxicol. Lett. 176, 1-12. doi: 10.1016/j.toxlet.2007.10.004

Coccia, F., Tonucci, L., Bosco, D., Bressan, M., and d'Alessandro, N. (2012). Onepot synthesis of lignin-stabilised platinum and palladium nanoparticles and their catalytic behaviour in oxidation and reduction reactions. Green Chem. 14, 1073-1078. doi: 10.1039/c2gc16524d

Dahoumane, S. A., Yepremian, C., Djediat, C., Couté A., Fiévet, F., Coradin, T., et al. (2016). Improvement of kinetics, yield, and colloidal stability of biogenic gold nanoparticles using living cells of Euglena gracilis microalga. J. Nanoparticle Res. 18:79. doi: 10.1007/s11051-016-3378-1

Dameron, C. T., Reese, R. N., Mehra, R. K., Kortan, A. R., Carroll, P. J., Steigerwald, M. L., et al. (1989). Biosynthesis of cadmium sulphide quantum semiconductor crystallites. Nature 338, 596-597. doi: 10.1038/338596a0

Das, D., Nath, B., Phukon, P., and Dolui, S. (2012). Synthesis and evaluation of antioxidant and antibacterial behavior of $\mathrm{CuO}$ nanoparticles. Colloids Surf. $B$ Biointerfaces 101C, 430-433. doi: 10.1016/j.colsurfb.2012.07.002

Das, D. R. K., Gogoi, N., and Bora, U. (2011). Green synthesis of gold nanoparticles using Nyctanthes arbortristis flower extract. Bioprocess Biosyst. Eng. 34, 615-619. doi: 10.1007/s00449-010-0510-y
Das, R. K., Pachapur, V. L., Lonappan, L., Naghdi, M., Pulicharla, R., Maiti, S., et al. (2017). Biological synthesis of metallic nanoparticles: plants, animals and microbial aspects. Nanotechnol. Environ. Eng. 2:18. doi: 10.1007/s41204-017-0029-4

Das, V. L., Thomas, R., Varghese, R. T., Soniya, E. V., Mathew, J., and Radhakrishnan, E. K. (2014). Extracellular synthesis of silver nanoparticles by the bacillus strain CS 11 isolated from industrialized area. 3 Biotech 4, 121-126. doi: 10.1007/s13205-013-0130-8

Deplanche, K., Caldelari, I., Mikheenko, I., Sargent, F., and Macaskie, L. (2010). Involvement of hydrogenases in the formation of highly catalytic $\mathrm{Pd}(0)$ nanoparticles by bioreduction of $\mathrm{Pd}(\mathrm{II})$ using Escherichia coli strains. Microbiology 156, 2630-2640. doi: 10.1099/mic.0.036681-0

Dhanalakshmi, T., and Rajendran, S. (2012). Synthesis of silver nanoparticles using Tridax procumbens and its antimicrobial activity. Arch. Appl. Sci. Res. 4, 1289-1293. Available online at: https://www.scholarsresearchlibrary.com/ articles/synthesis-of-silver-nanoparticles- using-tridax-procumbens-and-itsantimicrobial-activity.pdf

Dubey, S., Lahtinen, M., and Sillanpää M. (2010). Tansy fruit mediated greener synthesis of silver and gold nanoparticles. Process Biochem. 45, 1065-1071. doi: 10.1016/j.procbio.2010.03.024

Duran, N., and Seabra, A. (2012). Metallic oxide nanoparticles: state of the art in biogenic syntheses and their mechanisms. Appl. Microbiol. Biotechnol. 95, 275-288. doi: 10.1007/s00253-012-4118-9

Dwivedi, A., and Gopal, K. (2010). Biosynthesis of silver and gold nanoparticles using Chenopodium album leaf extract. Colloids Sur..A Physicochem. Eng. Asp. 369, 27-33. doi: 10.1016/).colsurfa. 2010.07:020

Espitia, P., Soares, N. Coimbra, J., Andrade, N., Cruz, R., and Medeiros, E. (2012). Zinc oxide nanoparticles: synthesis, antimicrobial activity and food packaging applications. Food Bioprocess Technol. 5, 1447-1464. doi: 10.1007/s1 1947-012-0797-6

Eustis, S., and El-Sayed, M. (2006). Why gold nanoparticles are more precious than pretty gold: noble metal surface plasmon resonance and its enhancement of the radiative and nonradiative properties of nanocrystals of different shapes. Chem. Soc. Rev 35, 209-217. doi: 10.1039/B514191E

ahlawat, G., and Roy Choudhury, A. (2019). A review on the biosynthesis of etal and metal salt nanoparticles by microbes. RSC Adv. 9, 12944-12967. .1039/C8RA10483B

Gardea-Torresdey, J., Parsons, J., Gomez, E., Peralta-Videa, J., Troiani, H., Santiago, P., et al. (2002). Formation and growth of Au nanoparticles inside live alfalfa plants. Nano Lett. 2:397. doi: 10.1021/nl015673+

Gardea-Torresdey, J. L., Tiemann, K. J., Gamez, G., Dokken, K., Tehuacanero, S., and José-Yacamán, M. (1999). Gold nanoparticles obtained by bioprecipitation from gold(III) solutions. J. Nanoparticle Res. 1, 397-404. doi: 10.1023/A:1010008915465

Gericke, M., and Pinches, A. (2006a). Microbial production of gold nanoparticles. Gold Bull. 39, 22-28. doi: 10.1007/BF03215529

Gericke, M., and Pinches, A. (2006b). Biological synthesis of metal nanoparticles. Hydrometallurgy 83, 132-140. doi: 10.1016/j.hydromet.2006. 03.019

Ghosh, S., and Pal, T. (2007). Interparticle coupling effect on the surface plasmon resonance of gold nanoparticles: from theory to applications. Chem. Rev. 107, 4797-4862. doi: 10.1021/cr0680282

Górzny, M., Walton, A., and Evans, S. (2010). Catalysis: synthesis of highsurface-area platinum nanotubes using a viral template. Adv. Funct. Mater. 20. doi: 10.1002/adfm.201090031

Govindaraju, K., Kiruthiga, V., Kumar, G., and Singaravelu, G. (2009). Extracellular synthesis of silver nanoparticles by a marine alga, Sargassum wightii grevilli and their antibacterial effects. J. Nanosci. Nanotechnol. 9, 5497-5501. doi: 10.1166/jnn.2009.1199

Gupta, R., and Xie, H. (2018). Nanoparticles in daily life: applications, toxicity and regulations. J. Environ. Pathol. Toxicol. Oncol. 37, 209-230. doi: 10.1615/JEnvironPatholToxicolOncol.2018026009

Haider, A., Ijaz, M., Ali, S., Haider, J., Imran, M., Majeed, H., et al. (2020). Green synthesized phytochemically (Zingiber officinale and Allium sativum) reduced nickel oxide nanoparticles confirmed bactericidal and catalytic potential. Nanoscale Res. Lett. 15:50. doi: 10.1186/s11671-020-3283-5

Hamouda, R., Hussein, M., Abo-elmagd, R., and Bawazir, S. (2019). Synthesis and biological characterization of silver nanoparticles derived 
from the cyanobacterium Oscillatoria limnetica. Sci. Rep. 9:13071. doi: 10.1038/s41598-019-49444-y

Hassan, M. S., Amna, T., Yang, O. B., El-Newehy, M., Al-Deyab, S., and Khil, M. S. (2012). Smart copper oxide nanocrystals: synthesis, characterization, electrochemical and potent antibacterial activity. Colloids Surf. B Biointerfaces 97, 201-206. doi: 10.1016/j.colsurfb.2012.04.032

He, S., Guo, Z., Zhang, Y., Zhang, S., and Ning, G. (2007). Biosynthesis of gold nanoparticles using the bacteria Rhodopseudomonas capsulata. Mater. Lett. 61, 3984-3987. doi: 10.1016/j.matlet.2007.01.018

Heinlaan, M., Ivask, A., Blinova, I., Dubourguier, H.-C., and Kahru, A. (2008). Toxicity of nanosized and bulk $\mathrm{ZnO}, \mathrm{CuO}$ and $\mathrm{TiO}_{2}$ to bacteria Vibrio fischeri and crustaceans Daphnia magna and Thamnocephalus platyurus. Chemosphere 71, 1308-1316. doi: 10.1016/j.chemosphere.2007.11.047

Hsiao, M.-T., Chen, S.-F., Shieh, D.-B., and Yeh, C.-S. (2006). One-pot synthesis of hollow $\mathrm{Au}_{3} \mathrm{Cul}$ spherical-like and biomineral botallackite $\mathrm{Cu}_{2}(\mathrm{OH})_{3} \mathrm{Cl}$ flowerlike architectures exhibiting antimicrobial activity. J. Phys. Chem. B 110, 205-210. doi: 10.1021/jp054827x

Hua, S., de Matos, M. B. C., Metselaar, J. M., Storm, G. (2018). Current trends and challenges in the clinical translation of nanoparticulate nanomedicines: pathways for translational development and commercialization. Front. Pharmacol. 9:790. doi: 10.3389/fphar.2018.00790

Huang, J., Li, Q., Sun, D., Lu, Y., Su, Y., Yang, X., et al. (2007). Biosynthesis of silver and gold nanoparticles by novel sundried Cinnamomum camphora leaf. Nanotechnology 18:105104. doi: 10.1088/0957-4484/18/10/105104

Huang, X., Jain, P., El-Sayed, I., and El-Sayed, M. (2006). Determination of the minimum temperature required for selective photothermal destruction of cancer cells with the use of immunotargeted gold nanoparticles. Photochem. Photobiol. 82, 412-417. doi: 10.1562/2005-12-14-RA-754

Hulkoti, N., and Taranath, T. (2014). Biosynthesis of nanoparticles using microbes-a review. Colloids Surf. B Biointerfaces 121, 474-483. doi: $10.1016 /$ j.colsurfb.2014.05.027

Husain, S., Sardar, M., and Fatma, T. (2015). Screening of cyanobacterial extracts for synthesis of silver nanoparticles. World J. Microbiol. Biotechnol. 31, 1279-1283. doi: 10.1007/s11274-015-1869-3

Husseiny, M., El-Aziz, M., Badr, Y., and Mahmoud, M. (2007). Biosynthesis of gold nanoparticles using Pseudomonas aeruginosa. Spectrochim. Acta A 67, 1003-1006. doi: 10.1016/j.saa.2006.09.028

Iravani, S., and Zolfaghari, B. (2013). Green synthesis of silver nanoparticles using pinus eldarica bark extract. Biomed Res. Int. 2013:639725. doi: $10.1155 / 2013 / 639725$

Jacob, J., Mukherjee, T., and Kapoor, S. (2012). A simple approach for facile synthesis of $\mathrm{Ag}$, anisotropic $\mathrm{Au}$ and bimetallic $(\mathrm{Ag} / \mathrm{Au})$ nanoparticles using cruciferous vegetable extracts. Mater Sci. Eng. C 32, 1827-1834. doi: 10.1016/j.msec.2012.04.072

Jain, N., Bhargava, A., Majumdar, S., Tarafdar, J., and Panwar, J. (2010). Extracellular biosynthesis and characterization of silver nanoparticles using aspergillus flavusNJP08: a mechanism perspective. Nanoscale 3, 635-641. doi: 10.1039/C0NR00656D

Jebakumar Immanuel Edison, T. N., and Sethuraman, M. (2012). Instant green synthesis of silver nanoparticles using Terminalia chebula fruit extract and evaluation of their catalytic activity on reduction of methylene blue. Process Biochem. 47. 1351-1357. doi: 10.1016/j.procbio.2012. 04.025

Jia, L., Zhang, Q., Li, Q., and Song, H. (2009). The biosynthesis of palladium nanoparticles by antioxidants in Gardenia jasminoides ellis: long lifetime nanocatalysts for p-nitrotoluene hydrogenation. Nanotechnology 20:385601. doi: 10.1088/0957-4484/20/38/385601

Joglekar, S., Kodam, K., Dhaygude, M., and Hudlikar, M. (2011). Novel route for rapid biosynthesis of lead nanoparticles using aqueous extract of Jatropha curcas L. latex. Mater. Lett. 65, 3170-3172. doi: 10.1016/j.matlet.2011. 06.075

Johnston, C. W., Wyatt, M. A., Li, X., Ibrahim, A., Shuster, J., Southam, G., et al. (2013). Gold biomineralization by a metallophore from a gold-associated microbe. Nat. Chem. Biol. 9, 241-243. doi: 10.1038/nchembio1179

Kahzad, N., and Salehzadeh, A. (2020). Green synthesis of $\mathrm{CuFe}_{2} \mathrm{O}_{4} @ \mathrm{Ag}$ nanocomposite using the Chlorella vulgaris and evaluation of its effect on the expression of norA efflux pump gene among Staphylococcus aureus strains. Biol. Trace Elem. Res 198:359-370. doi: 10.1007/s12011-020-02055-5
Kalimuthu, K., Babu, R., Venkataraman, D., and Gurunathan, S. (2008). Biosynthesis of silver nanocrystals by Bacillus licheniformis. Colloids Surf. B Biointerfaces 65, 150-153. doi: 10.1016/j.colsurfb.2008.02.018

Kanayairam, V., Rahuman, A., Rajakumar, G., Thirunavukkarasu, S., Marimuthu, S., Chidambaram, J., et al. (2011). Evaluation of Catharanthus roseus leaf extract-mediated biosynthesis of titanium dioxide nanoparticles against Hippobosca maculata and Bovicola ovis. Parasitol. Res. 111, 2329-37. doi: 10.1007/s00436-011-2676-x

Kasthuri, J., Kathiravan, K., and Rajendiran, N. (2008). Phyllanthin-assisted biosynthesis of silver and gold nanoparticles: a novel biological approach. $J$. Nanoparticle Res. 11, 1075-1085. doi: 10.1007/s11051-008-9494-9

Kaviya, S., Santhanalakshmi, J., Viswanathan, B., Muthumary, J., and Srinivasan, K. (2011). Biosynthesis of silver nanoparticles using citrus sinensis peel extract and its antibacterial activity. Spectrochim. Acta A Mol. Biomol. Spectrosc. 79, 54-598. doi: 10.1016/j.saa.2011.03.040

Keat, C. L., Aziz, A., Eid, A. M., and Elmarzugi, N. A. (2015). Biosynthesis of nanoparticles and silver nanoparticles. Bioresourc. Bioprocess. 2:47. doi: 10.1186/s40643-015-0076-2

Kemp, M., Kumar, A., Mousa, S., Park, T.-J., Ajayan, P., Kubotera, N., et al. (2009). Synthesis of gold and silver nanoparticles stabilized with glycosaminoglycans having distinctive biological activities. Biomacromolecules 10, 589-595. doi: 10.1021/bm801266t

Khan, A., Fox, E., Górzny, M., Nikulina,E., Brougham, D., Wege, C., et al. (2013). $\mathrm{pH}$ control of the electrostatic binding of gold and iron oxide nanoparticles to tobacco mosaic virus. Langmuir 29, 2094-2098. doi: 10.1021/la3044126

Khare, P., and Bisen, P. S. (1991). Mitigating effect of physico-chemical factors ON $\mathrm{Ni}^{2+} \mathrm{Hg}^{2+}$ and $\mathrm{Cu}^{2+}$ toxicity in cylindrospermum Iu 942. Environ. Technol. 12, 297-301. doi. 10.1080/09593339109385009

Kobayashi, M. Tomita, S., Sawada, K., Shiba, K., Yanagi, H., Yamashita, I., et al. (2012) Chiral meta-molecules consisting of gold nanoparticles and genetically engineered tobacco mosaic virusA new tobacco mosaic virus vector and its use for the systemic production of angiotensin-I-converting enzyme inhibitor in transgenic tobacco. Opt. Express 20, 24856-24863. doi: 10.1364/OE.20.024856

Koduru, M. Golla, N. Dillip, D. G. R., Praveen, B., Bojja, S., Ch, L., et al. (2011). Green synthesis of silver nanoparticles using ocimum leaf extract and their aracterization. Digest J. Nanomater. Biostruct. 6, 181-186.

I., Ashtaputre, S., Kharrazi, S., Vogel, W., Urban, J., Kulkarni, S., et al. (2003). Extracellular synthesis of silver nanoparticles by a silver-tolerant yeast strain MKY3. Nanotechnology 14, 95-100. doi: 10.1088/0957-4484/14/1/321

Kowshik, M., Deshmukh, N., Vogel, W., Urban, J., Kulkarni, S., and Paknikar, K. (2002b). Microbial synthesis of semiconductor CdS nanoparticles, their characterization, and their use in the fabrication of an ideal diode. Biotechnol. Bioeng. 78, 583-588. doi: 10.1002/bit.10233

Kowshik, M., Vogel, W., Urban, J., Kulkarni, S., and Paknikar, K. (2002a). Microbial synthesis of semiconductor $\mathrm{PbS}$ nanocrystallites. Adv. Mater. 14, 815-818. doi: 10.1002/1521-4095(20020605)14:11<815::aid-adma815>3.0.co;2-k

Kreibig, U., and Vollmer, M. (2013). Optical Properties of Metal Clusters. Berlin; Heidelberg: Springer Science and Business Media.

Krishnaraj, C., Enthai Ganeshan, J., Seetharaman, R., Kumar, S., Kalaichelvan, P., and Mohan, N. (2009). Synthesis of silver nanoparticles using Acalypha indica leaf extracts and its antibacterial activity against water borne pathogens. Colloids Surf. B Biointerfaces 76, 50-56. doi: 10.1016/j.colsurfb.2009.10.008

Kulkarni, N., and Muddapur, U. (2014). Biosynthesis of metal nanoparticles: a review. J. Nanotechnol. 2014:510246. doi: 10.1155/2014/510246

Kumar, P., Singh, P., Kumari, K., Mozumdar, S., and Chandra, R. (2011). A green approach for the synthesis of gold nanotriangles using aqueous leaf extract of Callistemon viminalis. Mater. Lett. 65, 595-597. doi: 10.1016/j.matlet.2010.11.025

Kumar, V., and Yadav, S. (2009). Plant-mediated synthesis of silver and gold nanoparticles and their applications. J. Chem. Technol. Biotechnol. 84, 151-157. doi: $10.1002 /$ jctb. 2023

Kundu, S., Ghosh, S., Mandal, M., Pal, T., and Pal, A. (2002). Silver and gold nanocluster catalyzed reduction of methylene blue by arsine in a micellar medium. Bull. Mater. Sci. 25, 577-579. doi: 10.1021/la0201974

Laokula, P., Klinkaewnaronga, J., Phokha, S., and Seraphin, S. (2008). Indium oxide $\left(\operatorname{In}_{2} \mathrm{O}_{3}\right)$ nanoparticles using Aloe vera plant extract: synthesis and optical properties. Optoelectron. Adv. Mater. Rapid Commun. 2, 161-165. 
Laudenslager, M., Schiffman, J., and Schauer, C. (2008). Carboxymethyl chitosan as a matrix material for platinum, gold, and silver nanoparticles. Biomacromolecules 9, 2682-2685. doi: 10.1021/bm800835e

Lee, H. J., Lee, G., Jang, N. R., Yun, J. H., Song, J. Y., and Kim, B. S. (2011). "Biological synthesis of copper nanoparticles using plant extract," in Technical Proceedings of the 2011 NSTI Nanotechnology Conference and Expo, NSTI-Nanotech 2011, Vol. 1 (Boston; Abington, MA : CRC Press), 371-374. Available online at: https:/www.tib.eu/en/search/id/BLCP\%3ACN080786126/ Biological-synthesis-of-copper-nanoparticles-using/

Lee, H. J., Song, J., and Kim, B. S. (2013). Biological synthesis of copper nanoparticles using Magnolia kobus leaf extract and their antibacterial activity. J. Chem. Technol. Biotechnol. 88:4052. doi: 10.1002/jctb.4052

Lee, K. X., Shameli, K., Yew, Y. P., Teow, S.-Y., Jahangirian, H., RafieeMoghaddam, R., et al. (2020). Recent developments in the facile bio-synthesis of gold nanoparticles (AuNPs) and their biomedical applications. Int. J. Nanomed. 15, 275-300. doi: 10.2147/IJN.S233789

Lee, S.-W., Mao, C., Flynn, C. E., and Belcher, A. M. (2002). Ordering of quantum dots using genetically engineered viruses. Science 296, 892-895. doi: $10.1126 /$ science. 1068054

Lengke, M., Fleet, M., and Southam, G. (2007). Biosynthesis of silver nanoparticles by filamentous cyanobacteria from a silver(I) nitrate complex. Langmuir 23 , 2694-2699. doi: 10.1021/la0613124

Lengke, M. F., Ravel, B., Fleet, M. E., Wanger, G., Gordon, R. A., and Southam, G. (2006). Mechanisms of gold bioaccumulation by filamentous cyanobacteria from gold(III)-chloride complex. Environ. Sci. Technol. 40, 6304-6309. doi: 10.1021/es061040r

Lin, X., Wu, M., Wu, D., Kuga, S., Endo, T., and Huang, Y. (2011). Platinum nanoparticles using wood nanomaterials: eco-friendly synthesis, shape control and catalytic activity for p-nitrophenol reduction. Green Chem. 13, 283-287. doi: 10.1039/C0GC00513D

Lloyd, J., Yong, P., and Macaskie, L. (1998). Enzymatic recovery of elemental palladium by using sulfate-reducing bacteria. Appl. Environ. Microbiol. 64, 4607-4609. doi: 10.1128/AEM.64.11.4607-4609.1998

Love, A., Makarov, V., Yaminsky, I., Kalinina, N., and Taliansky, M. (2014). The use of tobacco mosaic virus and cowpea mosaic virus for the production of novel metal nanomaterials. Virology 449, 133-139. doi: 10.1016/j.virol.2013.11.002

Luangpipat, T., Beattie, I., Chisti, Y., and Haverkamp, R. (2011) Gold nanoparticles produced in a microalga. J. Nanoparticle Res. 13, 6439-6445. doi: 10.1007/s11051-011-0397-9

Lukman, A., Gong, B., Marjo, C., Roessner, U. Facile synthesis, stabilization, and anti-bacterial performance of discrete Ag nanoparticles using Medicago sativa seed exudates. . Colloid Interface Sci 353,
433-444. doi: 10.1016/j.jcis.2010.09.088

Ma, Y., Li, N., Yang, C., and Yang, X. (2005). One-step synthesis of amino-dextranprotected gold and silver nanoparticles and ts application in biosensors. Anal. Bioanal. Chem. 382, 1044-1048. doi: 10.1007/s00216-005-3222-4

Makarov, V., Love, A. J., Sinitsyna, O., Makarova, S., Yaminsky, I., Taliansky, M., et al. (2014). "Green" nanotechnologies: synthesis of metal nanoparticles using plants. Acta Nat. 6, 35-44. doi: 10.32607/20758251-2014-6-1-35-44

Mallick, K., Witcomb, M., and Scurrell, P (2006). Silver nanoparticle catalysed redox reaction: an electron relay effect. Mater. Chem. Phys. 97, 283-287. doi: 10.1016/j.matchemphys.2005.08.011

Mandal, D., Bolander, M., Mukhopadhyay, D., Sarkar, G., and Mukherjee, P. (2006). The use of microorganism for the formation of metal nanoparticles and their application. Appl. Microbiol. Biotechnol. 69, 485-492. doi: 10.1007/s00253-005-0179-3

Mao, C., Flynn, C. E., Hayhurst, A., Sweeney, R., Qi, J., Georgiou, G., et al. (2003). Viral assembly of oriented quantum dot nanowires. Proc. Natl. Acad. Sci. U.S.A. 100, 6946-6951. doi: 10.1073/pnas.0832310100

Mata, Y., Torres, E., Blázquez, M. L., Ballester, A., González, F., and Muñoz, J. (2008). Gold(III) biosorption and bioreduction with the brown alga Fucus vesiculosus. J. Hazard. Mater. 166, 612-618. doi: 10.1016/j.jhazmat.2008.11.064

McFarland, A., and Duyne, R. (2003). Single silver nanoparticles as realtime optical sensors with zeptomole sensitivity. Nano Lett. 3, 1057-1062. doi: $10.1021 /$ nl034372s

Medvedeva, N. V., Ipatova, O. M., Ivanov, Y. D., Drozhzhin, A. I., and Archakov, A. I. (2007). Nanobiotechnology and nanomedicine. Biochem. (Moscow) Suppl. B Biomed. Chem. 1, 114-124. doi: 10.1134/S1990750807020023
Merzlyak, A., and Lee, S.-W. (2006). Phage as templates for hybrid materials and mediators for nanomaterial synthesis. Curr. Opin. Chem. Biol. 10, 246-252. doi: 10.1016/j.cbpa.2006.04.008

Mittal, A. K., Chisti, Y., and Banerjee, U. (2013). Synthesis of metallic nanoparticles using plant extracts. Biotechnol. Adv. 31, 346-356. doi: 10.1016/j.biotechadv.2013.01.003

Mohanpuria, P., Rana, N. K., and Yadav, S. K. (2008). Biosynthesis of nanoparticles: technological concepts and future applications. J. Nanoparticle Res. 10, 507-517. doi: 10.1007/s11051-007-9275-x

Mondal, S., Laskar, R., Sk, I., Basu, S., Mandal, D., and Begum, N. A. (2010). Biogenic synthesis of $\mathrm{Ag}, \mathrm{Au}$ and bimetallic $\mathrm{Au} / \mathrm{Ag}$ alloy nanoparticles using aqueous extract of mahogany (Swietenia mahogani JACQ.) leaves. Colloids Surf. B Biointerfaces 82, 497-504. doi: 10.1016/j.colsurfb.2010.10.007

Mousavi, S. M., Hashemi, S. A., Younes, G., Atapour, A., Amani, A., Savardashtaki, A., et al. (2018). Green synthesis of silver nanoparticles toward bio and medical applications: review study. Artif. Cells 46, S855-72. doi: 10.1080/21691401.2018.1517769

Mukherjee, P., Ahmad, A., Mandal, D., Senapati, S., Sainkar, S., Khan, M., et al. (2001). Fungus-mediated synthesis of silver nanoparticles and their immobilization in the mycelial matrix: a novel biological approach to nanoparticle synthesis. Nano Lett. 1, 515-519. Roi: 10.1021/nl0155274

Mukherjee, P., Senapati, S., Mandal, D., Ahmad, A., Khan, M., Kumar, R., et al. (2002). Extracellular synthesis of gold nanoparticles by the fungus. Chembiochem. 3:461-3. doi: 10.1002/1439-7633(20020503)3:5<461::aid-cbic461>3.0.co;2-x

Nair, B., and Thalappil, P. (2002). Coalescence of nanoclusters and formation of submicron crystallites assisted by lactobacillus strains. Cryst. Growth Des. 2, 293-298. doi: $10.1021 / \mathrm{cg} 0255164$

Narayanan, K., and Sakthivel, N. (2011). Green synthesis of biogenic metal nanoparticles by terrestrial and aquatic phototrophic and heterotrophic eukaryotes and biocompatible agents. Adv. Colloid Interface Sci. 169, 59-79. doi: 10.1016/j.cis.2011.08.00

Narayanan, K. B., and Sakthivel, N. (2010). Phytosynthesis of gold nanoparticles using leaf extract of coleus amboinicus lour. Mater. Charact. 61, 1232-1238. doi: 10.1016/j.matchar.2010.08.003

Nevalainen, H., Suominen, P., and Taimisto, K. (1994). On the safety of Trichoderma reesei. J. Biotechnol. 37, 193-200. doi 10.1016/0168-1656(94)90126-0

jagi, E., Huang, H., Stafford, L., Genuino, H., Galindo, H., Collins, J., et al. (2011). Biosynthesis of iron and silver nanoparticles at room temperature using aqueous sorghum bran extracts. Langmuir 27, 264-271. doi: 10.1021/la103190n

Paciotti, G., Myer, L., Weinreich, D., Goia, D., Pavel, N., McLaughlin, R., et al. (2004). Colloidal gold: a novel nanoparticle vector for tumor directed drug delivery. Drug Deliv. 11, 169-183. doi: 10.1080/10717540490433895

Padil, V., and Cernik, M. (2013). Green synthesis of copper oxide nanoparticles using gum karaya as a biotemplate and their antibacterial application. Int. J. Nanomed. 8, 889-898. doi: 10.2147/IJN.S40599

Pantidos, N., and Horsfall, L. E. (2014). Biological synthesis of metallic nanoparticles by bacteria, fungi and plants. J. Nanomed. Nanotechnol. 5:233. doi: 10.4172/2157-7439.1000233

Parial, D., and Pal, R. (2011). Green synthesis of gold nanoparticles using cyanobacteria and their characterization. Indian J. Appl. Res. 4, 69-72. doi: 10.15373/2249555X/JAN2014/22

Parikh, R., Singh, S., Blv, P., Patole, M., Sastry, M., and Shouche, Y. (2008). Extracellular synthesis of crystalline silver nanoparticles and molecular evidence of silver resistance from morganella sp.: towards understanding biochemical synthesis mechanism. Chembiochem 9, 1415-1422. doi: $10.1002 /$ cbic. 200700592

Park, Y., Hong, Y. N., Weyers, A., Kim, Y. S., and Linhardt, R. (2011). ChemInform abstract: polysaccharides and phytochemicals: a natural reservoir for the green synthesis of gold and silver nanoparticles. IET Nanobiotechnol. 5, 69-78. doi: 10.1049/iet-nbt.2010.0033

Parker, H. L., Rylott, E. L., Hunt, A. J., Dodson, J. R., Taylor, A. F., Bruce, N. C., et al. (2014). Supported palladium nanoparticles synthesized by living plants as a catalyst for suzuki-miyaura reactions. PLOS ONE 9:e87192. doi: 10.1371/journal.pone.0087192

Patel, V., Berthold, D., Puranik, P., and Gantar, M. (2015). Screening of cyanobacteria and microalgae for their ability to synthesize silver 
nanoparticles with antibacterial activity. Biotechnol. Rep. 5, 112-119. doi: 10.1016/j.btre.2014.12.001

Pattanayak, M., and Nayak, P. (2013). Green synthesis and characterization of zero valent iron nanoparticles from the leaf extract of Azadirachta indica (Neem). World J. Nano Sci. Technol. 2, 6-9. Available online at: https://idosi.org/wjnst/ 2(1) $13 / 2 . p d f$

Petla, R. K., Vivekanandhan, S., Misra, M., Mohanty, A., and Satyanarayana, N. (2012). Soybean (Glycine max) leaf extract based green synthesis of palladium nanoparticles. J. Biomater. Nanobiotechnol. 3, 14-19. doi: $10.4236 /$ jbnb.2012.31003

Philip, D. (2010). Green synthesis of gold and silver nanoparticles using Hibiscus rosa sinensis. Phys. E:Low Dimens. Syst. Nanostruct. 42, 1417-1424. doi: 10.1016/j.physe.2009.11.081

Pimprikar, P., Joshi, S., Kumar, A. R., Zinjarde, S., and Kulkarni, S. (2009). Influence of biomass and gold salt concentration on nanoparticle synthesis by the tropical marine yeast Yarrowia lipolytica NCIM 3589. Colloids Surf. B Biointerfaces 74, 309-316. doi: 10.1016/j.colsurfb.2009.07.040

Poinern, G. E. J., Chapman, P., Shah, M., and Fawcett, D. (2013). Green biosynthesis of silver nanocubes using the leaf extracts from Eucalyptus macrocarpa. Nano Bull. 2:130101. Available online at: http://hdl.handle.net/20. $500.11937 / 49096$

Pollmann, K., Raff, J., Mohamed, M., Fahmy, K., and Selenska-Pobell, S. (2006). Metal binding by bacteria from uranium mining waste piles and its technological applications. Biotechnol. Adv. 24, 58-68. doi: 10.1016/j.biotechadv.2005.06.002

Pugazhenthiran, N., Anandan, S., Kathiravan, G., Udaya Prakash, N. K., Crawford, S., and Ashokkumar, M. (2009). Microbial synthesis of silver nanoparticles by Bacillus sp. J. Nanoparticle Res. 11:1811. doi: 10.1007/s11051-009-9621-2

$\mathrm{Qu}$, J., Luo, C., and Hou, J. (2011a). Synthesis of $\mathrm{ZnO}$ nanoparticles from $\mathrm{Zn}$ hyperaccumulator (Sedum alfredii Hance) plants. Micro Nano Lett. IET 6, 174-176. doi: 10.1049/mnl.2011.0004

Qu, J., Yuan, X., Wang, X., and Shao, P. (2011b). Zinc accumulation and synthesis of $\mathrm{ZnO}$ nanoparticles using Physalis alkekengi L. Environ. Pollut. 159, 1783-1788. doi: 10.1016/j.envpol.2011.04.016

Rai, M., Yadav, A., and Gade, A. (2008). Silver nanoparticles as a new generation of antimicrobials. Biotechnol. Adv. 27, 76-83. doi: 10.1016/j.biotechadv.2008.09.002

Rajakumar, G., Rahuman, A., Priyamvada, B., Khanna, G., Kumar, D., Sujin, P., et al. (2011). Author's personal copy Eclipta prostrata leaf aqueous extract mediated synthesis of titanium dioxide nanoparticles. Mater. Lett. 68,115-117. doi: 10.1016/j.matlet.2011.10.038

Rajasulochana, P., Dhamotharan, R., Murugakoothan, P., Subbiah, M.y and Krishnamoorthy, P. (2011). Biosynthesis and characterization of gold nanoparticles using the alga Kappaphycus alvarezii. Int. X. Nanosci. 9, 511-516. doi: 10.1142/S0219581X10007149

Ramanathan, R., Field, M., O'Mullane, A., Smooker, P., Bhargava, S., and Bansal, V. (2013). Aqueous phase synthesis of copper nanoparticles: a link between heavy metal resistance and nanoparticle synthesis ability in bacterial systems. Nanoscale 5, 2300-2306. doi: 10.1039/C2NR32887A

Raveendran, P., Fu, J., and Wallen, S. (2003). Completely "green" synthesis and stabilization of metal nanoparticles. J. Am. Chem. Soc. 125, 13940-13941. doi: $10.1021 /$ ja029267j

Riddin, T. L., Gericke, M., and Whiteley, C. G. (2006). Analysis of the inter- and extracellular formation of platinum nanoparticles by Fusarium oxysporumf. sp.lycopersiciusing response surface methodology. Nanotechnology 17, 3482-3489. doi: 10.1088/0957-4484/17/14/021

Roh, Y., Lauf, R. J., McMillan, A. D., Zhang, C., Rawn, C., Bai, J., et al. (2001). Microbial synthesis and the characterization of metal-substituted magnetites. Solid State Commun. 118, 529-534. doi: 10.1016/S0038-1098(01)0 0146-6

Roopan, S., Thakur, R., Rahuman, A., Kamaraj, D. C., Annadurai, B., and Tammineni, S. (2013). Low-cost and eco-friendly bio-synthesis of silver nanoparticles using Cocos nucifera coir extract and its larvicidal activity. Ind. Crops Prod. 43, 31-635. doi: 10.1016/j.indcrop.2012.08.013

Roopan, S. M., Bharathi, A., Kumar, R., Khanna, V. G., and Prabhakarn, A. (2012). Acaricidal, insecticidal, and larvicidal efficacy of aqueous extract of Annona squamosa L peel as biomaterial for the reduction of palladium salts into nanoparticles. Colloids Surf. B Biointerfaces 92, 209-212. doi: 10.1016/j.colsurfb.2011.11.044

Roy, M., Mandal, B., Mukherjee, P., Mukherjee, P., Ghatak, J., Tyagi, A. K., et al. (2008). Green synthesis of highly stabilized nanocrystalline silver particles by a non-pathogenic and agriculturally important fungus T. asperellum. Nanotechnology 19:075103. doi: 10.1088/0957-4484/19/7/075103

Royston, E., Ghosh, A., Kofinas, P., Harris, M., and Culver, J. (2008). Self-assembly of virus-structured high surface area nanomaterials and their application as battery electrodes. Langmuir 24, 906-912. doi: 10.1021/la7016424

Saha, S., Pal, A., Kundu, S., Basu, S., and Pal, T. (2009). Photochemical green synthesis of calcium-alginate-stabilized $\mathrm{Ag}$ and $\mathrm{Au}$ nanoparticles and their catalytic application to 4-nitrophenol reduction. Langmuir 26, 2885-2893. doi: $10.1021 / 1 \mathrm{a} 902950 \mathrm{x}$

San Keskin, N. O., Koçberber KiliÇ N., Dönmez, G., and Tekinay, T. (2016). Green synthesis of silver nanoparticles using cyanobacteria and evaluation of their photocatalytic and antimicrobial activity. J. Nano Res. 40, 120-127. doi: 10.4028/www.scientific.net/JNanoR.40.120

Sangaru, S. S., Rai, A., Ahmad, A., and Sastry, M. (2004). Rapid synthesis of Au, $\mathrm{Ag}$, and bimetallic Au core-Ag shell nanoparticles using neem (Azadirachta indica) leaf broth. J. Colloid Interface Sci. 275, 496-502. doi: 10.1016/j.jcis.2004. 03.003

Sangeetha, G., Rajeshwari, S., and Rajendran, V. (2011). Green synthesis of zinc oxide nanoparticles by Aloe barbadensis miller leaf extract: structure and optical properties. Mater. Res. Bull. 46, 2560-2566. doi: 10.1016/j.materresbull.2011.07.046

Sanghi, R., and Verma, P. (2008). Biomimetic synthesis and characterisation of protein capped silver nanoparticles. Bioresour. Technol. 100, 501-504. doi: 10.1016/j.biortech.2008.05.048

Sastry, M., Ahmad, A., Khan, M., and Kumar, R. (2005). "Microbial nanoparticle production," in Chemosphere. eds. C. M. Niemeyer and C. A. Mirkin, 126-135. doi: $10.1002 / 3527602453$.

Sathishkumar, M., Sneha, K. Kwak, I., Mao, J., Tripathy, S. J., and Yun, Y.S. (2009a). Phyto-crystallization of palladium through reduction process using Cinnamom zeylanicum bark extract. J. Hazard. Mater. 171, 400-404. doi: 10.1016/j.jhazmat.2009.06.014

Sathishkumar, M., Sneha, K., Won, S. W., Cho, C.-W., Kim, S., and Yun, Y.S. (20096). Cinnamon zeylanicum bark extract and powder mediated green synthesis of nano-crystalline silver particles and its bactericidal activity. Colloids Surf. B Biointerfaces 73, 332-338. doi: 10.1016/j.colsurfb.2009. 06.005

Sathishkumar, M., Sneha, K., and Yun, Y.-S. (2010). Immobilization of silver nanoparticles synthesized using Curcuma loga tuber powder and extract on cotton cloth for bactericidal activity. Bioresour. Technol. 101, 7958-7965. doi: 10.1016/j.biortech.2010.05.051

Schlüter, M., Hentzel, T., Suarez, C., Koch, M., Lorenz, W., Böhm, L., et al. (2014). Synthesis of novel palladium $(0)$ nanocatalysts by microorganisms from heavy-metal-influenced high-alpine sites for dehalogenation of polychlorinated dioxins. Chemosphere 117C, 462-470. doi: 10.1016/j.chemosphere.2014. 07.030

Senapati, S., Syed, A., Moeez, S., Kumar, A., and Ahmad, A. (2012). Intracellular synthesis of gold nanoparticles using alga Tetraselmis kochinensis. Mater. Lett. 79, 116-118. doi: 10.1016/j.matlet.2012.04.009

Shah, S., Dasgupta, S., Chakraborty, M., Vadakkekara, R., and Hajoori, M. (2014). Green synthesis of iron nanoparticles using plant extracts. Int. J. Biol. Pharm. Res. 5, 549-552.

Shahverdi, A. R., Minaeian, S., Shahverdi, H., Jamalifar, H., and Nohi, A.-A. (2007). Rapid synthesis of silver nanoparticles using culture supernatants of enterobacteria: a novel biological approach. Process Biochem. 42, 919-923. doi: 10.1016/j.procbio.2007.02.005

Sharma, S. K., and Bisen, P. S. (1992). $\mathrm{Hg}^{2+}$ and $\mathrm{Cd}^{2+}$ induced inhibition of light induced proton efflux in the cyanobacterium anabaena flos-aquae. Biometals 5 , 163-167. doi: 10.1007/BF01061323

Sharma, S. K., Dhyani, S., Singh, D. P., Shukla, H. D., Ahmad, A., and Bisen, P. (2001). Influence of sodium ion on heavy metal-induced inhibition of light-regulatd proton efflux and active carbon uptake in the cyanobacterium anabaena flos-aquae. World J. Microbiol. Biotechnol. 17, 707-711. doi: 10.1023/A:1012931228452 
Shenton, W., Douglas, T., Young, M., Stubbs, G., and Mann, S. (1999). Inorganicorganic nanotube composites from template mineralization of tobacco mosaic virus. Adv. Mater. 11, 23-256.

Sheny, D. S., Mathew, J., and Philip, D. (2011). Phytosynthesis of Au, Ag and $\mathrm{Au}-\mathrm{Ag}$ bimetallic nanoparticles using aqueous extract and dried leaf of Anacardium occidentale. Spectrochim. Acta A Mol. Biomol. Spectrosc. 79, 254-262. doi: 10.1016/j.saa.2011.02.051

Shivaji, S., Deshmukh, A., and Sadowski, Z. (2014). Biosynthesis, optimization, purification and characterization of gold nanoparticles. Afr. J. Microbiol. Res. 8, 138-146. doi: 10.5897/AJMR10.143

Simon-Deckers, A., Loo, S., Mayne-L'hermite, M., Herlin Boime, N., Menguy, N., Reynaud, C., et al. (2009). Size-, composition- and shape-dependent toxicological impact of metal oxide nanoparticles and carbon nanotubes toward bacteria. Environ. Sci. Technol. 43, 8423-8429. doi: 10.1021/es90 16975

Singaravelu, G., Arockiamary, J., Kumar, G., and Govindaraju, K. (2007). A novel extracellular synthesis of monodisperse gold nanoparticles using marine alga, Sargassum wightii greville. Colloids Surf. B Biointerfaces 57, 97-101. doi: 10.1016/j.colsurfb.2007.01.010

Singh, D. P., Khare, P., and Bisen, P. (1989). Effect of $\mathrm{Ni}^{2+}, \mathrm{Hg}^{2+}$ and $\mathrm{Cu}^{2+}$ on growth, oxygen evolution and photosynthetic electron transport in cylindrospermum IU 942. J. Plant Physiol. 134, 406-412. doi: 10.1016/S0176-1617(89)80003-3

Singh, D. P., Sharma, S. K., and Bisen, P. (1993). Differential action of $\mathrm{Hg}^{2+}$ and $\mathrm{Cd}^{2+}$ on the phycobilisomes and chlorophyll a fluorescence and photosystem II dependent electron trnasport in the cyanobacterium anabaena flos-aquae. Biometals 6, 125-132. doi: 10.1007/BF00140114

Singh, P., Kim, Y.-J., Zhang, D., and Yang, D.-C. (2016). Biological synthesis of nanoparticles from plants and microorganisms. Trends Biotechnol. 34, 588-599. doi: 10.1016/j.tibtech.2016.02.006

Singh, R. (2011). Biological approach of zinc oxide nanoparticles formation and its characterization. Adv. Mater. Lett. 2, 313-317. doi: 10.5185/amlett.indias.204

Sintubin, L., De Windt, W., Dick, J., Mast, J., Van Der Ha, D., Verstraete, W., et al. (2009). Lactic acid bacteria as reducing and capping agent for the fast and efficient production of silver nanoparticles. Appl. Microbiol. Biotechnol. 84, 741-749. doi: 10.1007/s00253-009-2032-6

Sondi, I., and Salopek-Sondi, B. (2004). Silver nanoparticles as antimierobial agent: a case study on E. coli as a model for gram-negative bacteria. J. Colloid Interface Sci. 275, 177-182. doi: 10.1016/j.jcis.2004.02.012

Song, J., Jang, H.-K., and Kim, B. S. (2009a). B

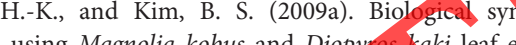
Biochem. 44, 1133-1138. doi: 10.1016/j.procbio.2009.06.005

Song, J., Kwon, E.-Y., and Kim, B. S. (2009b). Biological synthesis of platinum nanoparticles using Diopyros kaki leaf extract. Bioprocess Biosyst. Eng. 33, 159-164. doi: 10.1007/s00449-009-0373-2 )

Sotiriou, G., and Pratsinis, S. (2011). Engineering nanosilver as an antibacterial, biosensor and bioimaging material. Curr. Opin Chem. Eng. 1, 3-10. doi: 10.1016/j.coche.2011.07.00

Soundarrajan, C., Sankari, A., Dhandapani, P, Maruthamuthu, S., Ravichandran, S., Sozhan, G., et al. (2011). Rapid biologieal synthesis of platinum nanoparticles using Ocimum sanctum for water electrolysis applications. Bioprocess Biosyst. Eng. 35, 827-833. doi: 10.1007/s00449-011-0666-0

Spadaro, D., and Gullino, M. (2005). Improving the efficacy of biocontrol agents against soilborne pathogens. Crop Protect. 24, 601-613. doi: 10.1016/j.cropro.2004.11.003

Subhankari, I., and Nayak, P. (2013). Synthesis of copper nanoparticles using Syzygium aromaticum (Cloves) aqueous extract by using green chemistry. World J. Nano Sci. Technol. 2, 14-17.

Suganya, A., Murugan, K., Kovendan, K., Mahesh kumar, P., and Hwang, J.-S. (2013). Green synthesis of silver nanoparticles using Murraya koenigii leaf extract against Anopheles stephensi and Aedes aegypti. Parasitol. Res. 112, 1385-97. doi: 10.1007/s00436-012-3269-z

Sun, S., and Zeng, H. (2002). Size-controlled synthesis of magnetite nanoparticles. J. Am. Chem. Soc. 124, 8204-8205. doi: 10.1021/ja026501x

Sundrarajan, M., and Gowri, S. (2011). Green synthesis of titanium dioxide nanoparticles by Nyctanthes arbor-tristis leaves extract. Chalcogenide Lett. 8, 447-451.
Tang, S., Mao, C., Liu, Y., Kelly, D. Q., and Banerjee, S. K. (2007). Proteinmediated nanocrystal assembly for flash memory fabrication. IEEE Trans. Electron. Devices 54, 433-438. doi: 10.1109/TED.2006.890234

Tc, P., Raichur, A., Chandrasekaran, N., and Mukherjee, A. (2011). Kinetic evolution studies of silver nanoparticles in a bio-based green synthesis process. Colloids Surf. A Physicochem. Eng. Asp. 377, 212-216. doi: 10.1016/j.colsurfa.2010.12.047

Thakkar, K., Mhatre, S., and Parikh, R. (2009). Biological synthesis of metallic nanoparticles. Nanotechnol. Biol. Med. 6, 257-62. doi: 10.1016/j.nano.2009.07.002

Thakkar, K. N., Mhatre, S. S., and Parikh, R. Y. (2010). Biological synthesis of metallic nanoparticles. Nanomedicine 6, 257-262. doi: 10.1016/j.nano.2009.07.002

Thapa, D., Palkar, V. R., Kurup, M. B., and Malik, S. K. (2004). Properties of magnetite manoparticles synthesized through a novel chemical route. Mater. Lett. 58, 2692-2694. doi: 10.1016/j.matlet.2004.03.045

Thirunavukkarasu, S., Rahuman, A., Chidambaram, J., Rajakumar, G., Marimuthu, S., Kirthi, V., et al. (2013). Green synthesis of titanium dioxide nanoparticles using Psidium guajava extract and its antibacterial and antioxidant properties. Asian Pac. J. Trop. Med. 7, 968-976. doi:-10.1016/S1995-7645(14) 60171-1

Ummartyotin, S., Bunnak, N., Juntaro, J., Sain, M., and Manuspiya, H. (2012). Synthesis of colloidal silver nanoparticles for printed electronics. Comptes Rendus Chim. 15, 539-544. doi: 10.1016/j.crci.2012.03.006

Vahabi, K., Mansoori, G. A., and Karimi Dorcheh, S. (2011) Biosynthesis of silver nanoparticles by fungus Trichoderma reesei (a route for large-scale production of AgNPs). Insci. J. 1, 65-79. doi: 10.5640/insc.010165

Valodkar, M., Jadeja, R., Thounaojam, M. Devkar, R., and Thakore, S. (2011a). Biocompatible synthesis of peptide capped copper nanoparticles and their biological effect on tumor cells. Mater. Chem. Phys. 128, 83-89. doi:10.1016/j.matchemphys.2011.02.039

Valodkar, M., Nagar, P., Jadeja, R., Thounaojam, M., Devkar, R., and Thakore, S. (2011c). Euphorbiaceae latex induced green synthesis of non-cytotoxic metallic nanoparticle solutions: a rational approach to antimicrobial applications. Colloids Surf. A Physicochem. Eng. Asp. 384, 7-344. doi: 10.1016/j.colsurfa.2011.04.015

M., Rathore, P., Jadeja, R., Thounaojam, M., Devkar, R., and Thakore, S. 2011b). Cytotoxicity evaluation and antimicrobial studies of starch capped water soluble copper nanoparticles. J. Hazard. Mater. 20, 244-249. doi: 10.1016/j.jhazmat.2011.11.077

Veeraputhiran, V. (2013). Bio-catalytic synthesis of silver nanoparticles. Int. J. ChemTech Res. 5, 2555-2562.

Velmurugan, P., Lee, S.-M., Iydroose, M., Lee, K.-J., and Oh, B.-T. (2012). Pine cone-mediated green synthesis of silver nanoparticles and their antibacterial activity against agricultural pathogens. Appl. Microbiol. Biotechnol. 97, 361-8. doi: 10.1007/s00253-012-3892-8

Vimala, D. K., Sundarraj, S., Paulpandi, M., Srinivasan, V., and Kannan, S. (2013). Green synthesized doxorubicin loaded zinc oxide nanoparticles regulates the bax and Bcl-2 expression in breast and colon carcinoma. Process Biochem. 49, 160-172. doi: 10.1016/j.procbio.2013.10.007

Vivek, M., Kumar, P. S., Steffi, S., and Sudha, S. (2011). Biogenic silver nanoparticles by Gelidiella acerosa extract and their antifungal effects. Avicenna J. Med. Biotechnol. 3, 143-148.

Wang, L., Chen, X., Zhan, J., Chai, Y., Yang, C., Xu, L., et al. (2005). Synthesis of gold nano- and microplates in hexagonal liquid crystals. J. Phys. Chem. B 109, 3189-3194. doi: 10.1021/jp0449152

Waszczuk, P., Barnard, T., Rice, C., Masel, R., and Wieckowski, A. (2002). A nanoparticle catalyst with superior activity for electrooxidation of formic acid. Electrochem. Commun. 4:732. doi: 10.1016/S1388-2481(02) 00420-4

Xie, J., Lee, J. Y., Wang, D. I. C., and Ting, Y. P. (2007). Silver nanoplates: from biological to biomimetic synthesis. ACS Nano 1, 429-439. doi: $10.1021 / \mathrm{nn} 7000883$

Xu, X.-H. N., Brownlow, W. J., Kyriacou, S. V., Wan, Q., and Viola, J. J. (2004). Real-time probing of membrane transport in living microbial cells using single nanoparticle optics and living cell imaging. Biochemistry 43, 10400-10413. doi: 10.1021/bi036231a 
Yong, P., Rowson, N. A., Farr, J. P. G., Harris, I. R., and Macaskie, L. E. (2002). Bioaccumulation of palladium by Desulfovibrio desulfuricans. J. Chem. Technol. Biotechnol. 77, 593-601. doi: 10.1002/jctb.606

You, H., Yang, S., Ding, B., and Yang, H. (2013). Synthesis of colloidal metal and metal alloy nanoparticles for electrochemical energy applications. Chem. Soc. Rev. 42, 2880-2904. doi: 10.1039/C2CS35319A

Zahir, A., Chauhan, I., Bagavan, A., Kamaraj, D. C., Elango, G., Shankar, J., et al. (2015). Green synthesis of silver and titanium dioxide nanoparticles using Euphorbia prostrata extract shows shift from apoptosis to G $0 / \mathrm{G} 1$ arrest followed by necrotic cell death in leishmania donovani. Antimicrob. Agents Chemother. 59, 00098-00015. doi: 10.1128/AAC.00098-15
Conflict of Interest: The authors declare that the research was conducted in the absence of any commercial or financial relationships that could be construed as a potential conflict of interest.

Copyright () 2020 Zhang, Ma, Gu, Huang and Zhang. This is an open-access article distributed under the terms of the Creative Commons Attribution License (CC BY). The use, distribution or reproduction in other forums is permitted, provided the original author(s) and the copyright owner(s) are credited and that the original publication in this journal is cited, in accordance with accepted academic practice. No use, distribution or reproduction is permitted which does not comply with these terms.

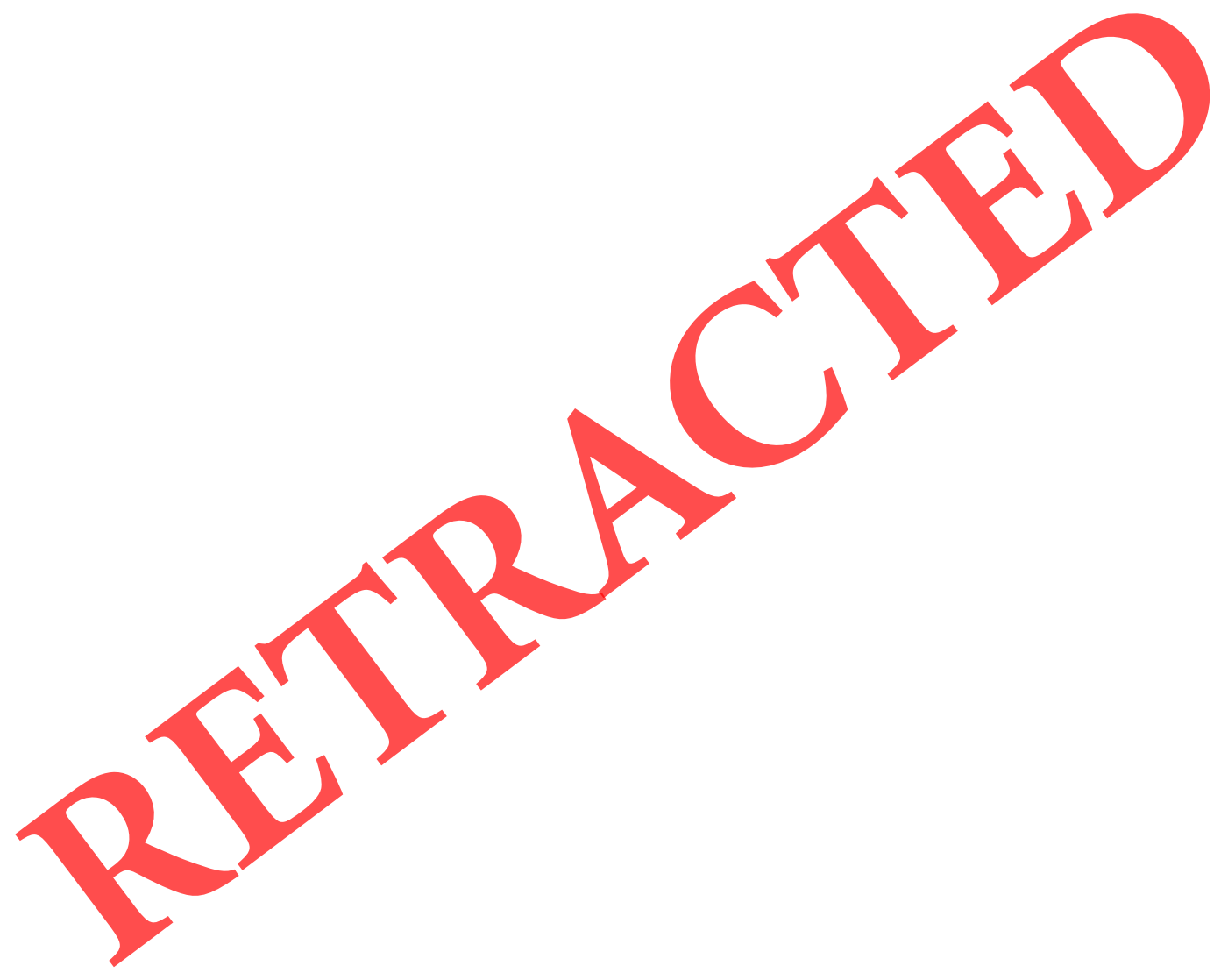

